$\begin{array}{lll}\text { KULTURA } & \text { POLSKA A KADEMIA NAUK } \\ \text { KOMITET SOCJOLOG I I } & \begin{array}{l}\text { KONN 0023-5172 } \\ \text { INSTYT T ST U DÓ W P O LIT Y CZNY C H }\end{array} \\ \text { SPOLECZENSTWO } & \text { 2015, nr 2 UKRAINA PRZED PRZEŁOMEM 2014 ROKU I PO }\end{array}$

TOMASZ STRYJEK

Instytut Studiów Politycznych PAN

\title{
DEBATA O DEKOMUNIZACJI NA UKRAINIE W 2015 ROKU: JAK POLITYCY „WYGRALI” Z INTELEKTUALISTAMI
}

\section{WPROWADZENIE USTAW}

W dniu 9 kwietnia 2015 r. Rada Najwyższa (RN) w Kijowie przyjęła cztery ustawy dekomunizacyjne określające na nowo politykę państwa wobec pamięci o epoce 1917-1991. Ustawy poparło około 60-65\% ogółu deputowanych niemal wszyscy członkowie pięciopartyjnej koalicji rządu Arsenija Jaceniuka. Wobec determinacji obozu rządzącego opozycja nie zdołała przeprowadzić debaty w parlamencie i ostatecznie nie wzięła udziału w głosowaniu. 15 maja 2015 r. prezydent Petro Poroszenko, wykorzystawszy cały czas przysługujący mu na podjęcie decyzji, podpisał ustawy. Zaczęly one obowiązywać w sześć dni później.

Celem moim jest analiza debaty publicznej na temat ustaw na Ukrainie trwającej w ciągu tych około sześciu tygodni. Chcę przedstawić jej charakter, przybliżyć argumentacje oraz wyjaśnić, dlaczego krytyczne głosy intelektualistów i ekspertów, przeważające ilościowo i jakościowo, nie wywarły wpływu na decyzje rządzących. Nie biorę pod uwagę stanowisk polityków, w tym najbardziej określonych: nacjonalistów i komunistów. Analiza jest też próbą rozpoznania pola intelektualnego Ukrainy $w$ jego wzajemnych relacjach $z$ jednej strony $z$ polem polityki (Bourdieu, Wacquant 2001), z drugiej - ze światem zewnętrznym.

W kwestii dekomunizacji nie zadziałały mechanizmy, zgodnie $z$ którymi demokracje parlamentarne wypracowują rozwiązania z udziałem władz pań-

Adres do korespondencji: tstryjek@wp.pl 
stwa, intelektualistów i ekspertów oraz opinii publicznej, uwzględniając przy tym zdania mniejszości. Prezydent mógł ustawy zawetować i w ten sposób „Zwrócić" je autorom do ponownego przygotowania (w parlamencie ukraińskim nie ma drugiej izby, która mogłaby korygować projekty przyjęte $\mathrm{w}$ pierwszej). Gdyby skorzystał z tego uprawnienia, debata, choć z opóźnieniem, odniosłaby skutek. Koalicja parlamentarna, rząd i głowa państwa dochowały wprawdzie formalnych zasad procesu ustawodawczego, jednak na rozstrzygnięciu tak trudnej kwestii w tak szybkim trybie nie skorzystało ani społeczeństwo obywatelskie, ani praworządność. A skądinąd Ukraina deklaruje, iż dąży do ich wzmocnienia bez względu na trwający konflikt wojenny.

Wiele wskazuje na to, że instytucja przygotowująca ustawy — podległy premierowi Ukraiński Instytut Pamięci Narodowej (UIPN) - nie była zainteresowana przeprowadzeniem debaty. Za pośrednictwem deputowanych i rządu projekty ustaw zgłoszono do prezydium Rady Najwyższej dopiero w dniach 3-7 kwietnia, nie pozostawiając czasu na pracę w komisjach. Wcześniej prezes Wołodymyr Wjatrowycz (2015a) i wiceprezes UIPN Ołeksandr Zinczenko (2015a, 2015b) wypowiadali się w mediach, jednak bardziej przekonując deputowanych do stworzenia „historycznego lobby” w parlamencie, niż informując społeczeństwo o treści ustaw. Brak ów pokrywano tłumaczeniem, że misją Instytutu jest przyczynienie się do... dialogu społecznego poprzez wyprowadzenie społeczeństwa $z$ traumy po doświadczeniach XX wieku. Okolicznością usprawiedliwiającą brak debaty i dobrego przygotowania ustaw nie może być też szczupłość kadrowa Instytutu (ok. 20 osób w całym kraju, głównie historyków). Jak się $\mathrm{w}$ toku debaty okazało, na brak fachowców, między innymi w dziedzinie ochrony praw człowieka, Ukraina nie może narzekać.

\section{POLSKI KONTEKST}

We wstępie warto też zwrócić uwagę, iż z powodu treści ustawy „O statusie prawnym i uczczeniu pamięci walczących o niepodległość Ukrainy w XX w.” (Ustawa o „walczących o niepodległość" 2015) oraz sposobu jej uchwalenia Ukraina naraziła na szwank stosunki ze swym zachodnim sąsiadem. W ustawie tej, zgłoszonej przez deputowanego Jurija Szuchewycza ${ }^{1}$, w katalogu uhonorowanych organizacji znalazły się między innymi Organizacja Ukraińskich Nacjonalistów (OUN) i Ukraińska Powstańcza Armia (UPA). Druga z nich w latach 1943-1944 przeprowadziła czystkę etniczną Polaków na Wołyniu i w Galicji

\footnotetext{
${ }^{1}$ Postać ta, obecnie patron organizacji nacjonalistycznej prawicy, ma w ukraińskim życiu publicznym wagę symbolu: ofiara rządów sowieckich, wieloletni więzień łagrów, represjonowany za niewyparcie się idei niepodległościowej i swego ojca Romana Szuchewycza (generał Szuchewycz był członkiem OUN i żołnierzem formacji złożonych z ukraińskich ochotników walczących w latach 1941-1942 po stronie III Rzeszy; zerwał z Niemcami i od 1943 roku, był dowódcą naczelnym UPA; zginął w 1950 roku w wyniku sowieckiej obławy).
} 
Wschodniej - niemal wszyscy historycy poza Ukrainą są co do tego zgodni. Ustawy uchwalono w kilka godzin po przemówieniu wygłoszonym w RN przez prezydenta Bronisława Komorowskiego, który składał właśnie oficjalną wizytę w Kijowie. Nie wiadomo, czy zbieżność tych dwu wydarzeń była przypadkowa, w każdym razie takie wyjaśnienie (nieoficjalnie) przedstawiły następnie władze Ukrainy $^{2}$.

W Polsce podniosły się głosy, iż projektodawcy wybrali tę datę ze względu na potrzebę zademonstrowania przez Ukrainę zupełnej niezależności nie tylko w stosunkach z Rosją, ale także z Polską (jednocześnie pozostałymi trzema ustawami prawie w ogóle się nie zajmowano). Dociekanie tego, jak było w istocie, nie jest moim celem. Warto jednak zauważyć, że o ile argument o dążeniu władz do odsunięcia od UPA odpowiedzialności za zbrodnię na Polakach był następnie w debacie ukraińskiej podnoszony, o tyle kwestia reakcji władz Polski czy polskiej opinii publicznej — nie (chyba że jako części całej opinii zagranicznej). Dla UIPN, jeśli idzie o Polskę, ważne jest przede wszystkim stanowisko Instytutu Pamięci Narodowej (IPN). Kierownictwo IPN w sprawie zbrodni UPA ma pogląd jednoznaczny, jednak daje partnerowi czas na wypracowanie stanowiska zbliżonego do polskiego. Kierownictwo UIPN zaś w planowanej dyskusji z polskimi historykami będzie dążyć, jak się wydaje, do zachowania generalnie pozytywnego wizerunku UPA, a tymczasem, w związku z ustawą o otwarciu archiwów, oferuje im szeroką współpracę $w$ badaniach, przede wszystkim nad ostatecznym wyjaśnieniem sowieckich zbrodni.

Jeśli zaś idzie o ukraińską opinię publiczną, to okazało się jedynie, iż zdanie Polaków w kwestiach dotyczących historii jest dla niej mniej ważne, niż im się $z$ reguły wydaje.

\section{UIPN - TWÓRCA USTAW}

Sam Wjatrowycz w przeddzień głosowania wybór jego daty uzasadnił tradycją prawosławną. W 2015 roku 9 kwietnia wypadł w dzień poprzedzający Niedzielę Wielkanocną, przez wyznawców chrześcijaństwa wschodniego nazywany Czystym Czwartkiem z uwagi na oczyszczanie się z grzechów przed zmartwychwstaniem Chrystusa (Wjatrowycz 2015b). Uzasadnienie to wiele mówi o sposobie myślenia młodych historyków, którzy w marcu 2014 roku, wychodząc niemal wprost $z$ Euromajdanu, $z$ nominacji premiera Jaceniuka objęli kierownictwo UIPN i weszli w rolę inspiratorów nowej polityki wobec pamięci państwowej (instytut utworzył jeszcze prezydent Juszczenko w 2006 r.). Zostali oni powołani w ramach wymiany kadr w administracji na ludzi reprezentujących trzeci sektor. Wjatrowycz i paru jego współpracowników przeszło do Kijowa z niepaństwowego Centrum Badań nad Ruchem Wyzwoleńczym we

2 Tuż przed I turą wyborów głowy państwa w Polsce Komorowski (2015) skrytykował ustawę za ograniczenie wolności badań nad OUN i UPA. 
Lwowie. W półtora roku po przełomie z lutego 2014 roku można było zauważyć, że aktywiści rewolucji nie przejęli kierowania państwem, lecz albo zostali włączeni do dotychczasowej elity, albo politycznie zmarginalizowani. Byli reprezentowani w nowym parlamencie, jednak funkcji kierowniczych we władzy wykonawczej, poza UIPN, w zasadzie już nie piastowali.

Wjatrowycz w latach 2008-2010 był już dyrektorem archiwum Służby Bezpieczeństwa Ukrainy w Kijowie, gdzie przechowywano dokumenty sowieckich służb, i nieformalnym doradcą Juszczenki do spraw polityki wobec pamięci. Jego prace historyczne zawierały interpretację jednostronnie uwalniającą od zarzutów: OUN o antysemityzm i udział w pogromach antyżydowskich w 1941 roku (Wjatrowycz 2006), UPA zaś - o przeprowadzenie czystki na Polakach w latach 1943-1944 (Wjatrowycz 2011). Siła wpływu UIPN po rewolucji pochodziła przede wszystkim z umiejętności posługiwania się przez jego kierownictwo językiem prostym, a jednocześnie nasyconym odwołaniami do wartości demokratycznych i niepodległościowych oraz do poczucia godności narodowej. Gdy Wjatrowycz - we wspomnianym uzasadnieniu - pisał, iż Ukraina stanie się państwem europejskim właśnie dzięki temu, że przyjmując ustawy dekomunizacyjne, ostatecznie zagwarantuje swym obywatelom „niepowtórzenie się w przyszłości praktyk totalitaryzmu”, nadal reprezentował tę rewolucyjną odrodzeniową retorykę, którą półtora roku wcześniej stworzyli liderzy występujący na scenie kijowskiego Euromajdanu. Jednak zapotrzebowanie na nią w społeczeństwie systematycznie malało. O ile naczelnym tematem 2014 roku była rewolucja i wojna, o tyle w roku następnym uwaga opinii publicznej była już skoncentrowana na tym, czy nowe władze wyciągną kraj z zapaści gospodarczej i wprowadzą reformy ustrojowe warunkujące członkostwo w UE.

\section{CO ZAWIERAJĄ USTAWY}

Ustawa, która jako jedyna przykuła uwagę polskiej opinii publicznej, ma charakter przede wszystkim legitymizacyjny. Przyznaje ona in gremio ogólnikowy status „walczących o niezależność Ukrainy” członkom parudziesięciu struktur państwa oraz organizacji wojskowych i cywilnych sprzeciwiających się w latach 1917-1991 obcej władzy na terytorium Ukrainy, w tym wymienia $z$ jednej strony OUN i UPA, z drugiej - ruchy dysydenckie $z$ lat sześćdziesiątych-osiemdziesiątych. Zobowiązuje też państwo do badania i popularyzowania wiedzy o ich działalności oraz stania na straży poglądu, iż to właśnie dzięki nim ustanowiono niepodległość w 1991 roku. Ustawa nie nadaje im praw kombatantów ani nie odbiera ich weteranom armii oraz partyzantki sowieckiej. Nie przyznaje im ulg i przywilejów socjalnych, lecz jedynie dopuszcza możliwość ich przyznania przez władze centralne czy samorządowe. Nie uznaje UPA za „stronę walczącą w drugiej wojnie światowej”, o co od dawna zabiegały organizacje ochrony jej pamięci, ani w żaden inny sposób jej nie wy- 
różnia. Nie wymienia tych ukraińskich struktur, które walczyły przeciw ZSRR, a jednocześnie wprost współpracowały z III Rzeszą, jak rząd Jarosława Stećki, powołany przez frakcję OUN Stepana Bandery 30 czerwca 1941 r., oraz Dywizja Waffen SS „Hałyczyna”, utworzona z udziałem frakcji OUN Andrija Melnyka w latach 1943-1944.

Ustawa określa jako łamanie prawa „zaprzeczanie faktu legalności walki o niepodległość Ukrainy w XX wieku”. Publiczne głoszenie takiego poglądu traktuje jako „obrazę” uczestników walki. Zakazując tego, ustawodawca nie określił jednak rodzaju odpowiedzialności sprawcy (karna, cywilna, administracyjna?), nie przewidział też żadnej sankcji i — co w tej sytuacji zrozumiałe — nie wprowadził jej do kodeksu karnego.

W zmianie legitymizacji historycznej państwa władze Ukrainy nie posunęły się jednak tak daleko, jak proponował projektodawca Szuchewycz. W stosunku do pierwotnej wersji usunięto zapis, iż współczesne państwo ukraińskie jest następcą prawnym Ukraińskiej Republiki Ludowej z 1918 roku, co jednoznacznie wskazywało na Rosję Radziecką (następnie ZSRR) jako władzę okupacyjną, a także o obligatoryjnym przyznaniu bojownikom ulg i przywilejów. Jednocześnie do listy organizacji dodano Ludowy Ruch Ukrainy na rzecz Przebudowy w zakresie jego działalności w latach 1989-1991, choć na początku nie był on organizacją niepodległościową i miał w swoich szeregach wielu członków partii komunistycznej (Olszański 2015).

Z kolei ustawa „O uwiecznieniu zwycięstwa nad nazizmem w drugiej wojnie światowej 1939-1945" (Ustawa o drugiej wojnie światowej 2015) usuwa z oficjalnego obiegu termin „Wielka Wojna Ojczyźniana”, dotyczący udziału USRR w walce przeciw III Rzeszy w latach 1941-1945. Wprowadzenie nazwy „druga wojna światowa 1939-1945” oznacza przyjęcie poglądu, zgodnie z którym istotą wydarzeń rozgrywających się przez te sześć lat na obszarze dzisiejszej Ukrainy była nie obrona państwa sowieckiego, lecz walka o jej niepodległość oraz zjednoczenie terytorialne.

$\mathrm{W}$ intencji projektodawców ustawa ma służyć wewnętrznemu pojednaniu w kraju oraz ostatecznemu włączeniu narracji o jego historii w kontekst europejski. Wyraża się to $\mathrm{w}$ ustanowieniu 8 maja - to jest dnia, w którym w państwach UE obchodzi się rocznicę zakończenia wojny — „nowym” Dniem Pamięci i Pojednania i pozostawieniu zarazem 9 maja, „starego” święta sowieckiego, tyle że w formie zawierającej już nową nazwę konfliktu — Dzień Zwycięstwa nad nazizmem w drugiej wojnie światowej (tylko drugi z nich jest nadal wolny od pracy). Ustawa jest spójna $z$ aktem poprzednio omówionym, gdyż $\mathrm{w}$ równy sposób traktuje weteranów sowieckich oraz „walczących o niepodległość" Ukrainy. Zawarto $\mathrm{w}$ niej sformułowanie, które obciąża państwo odpowiedzialnością za „niedopuszczenie do fałszowania obrazu drugiej wojny światowej w latach 1939-1945 w pracach naukowych, literaturze metodycznej, podręcznikach, środkach masowej informacji, publicznych wystąpieniach przedstawicieli organów państwowych". 
Z kolei celem ustawy „O dostępie do archiwów organów represyjnych totalitarnego reżimu komunistycznego z lat 1917-1991" (Ustawa o archiwach 2015) jest rozwój badań nad tym okresem oraz zapewnienie obywatelom możliwości zapoznania się z materiałami zgromadzonymi na ich temat. Postępując za rozwiązaniami przyjętymi $\mathrm{w}$ Polsce, postanowiono, iż wszystkie instytucje spadkobiercze organów bezpieczeństwa ZSRR mają w ciągu dwu lat przekazać swe zasoby dotyczące okresu do 1991 roku do nowego Oddziałowego Archiwum UIPN w Kijowie. Ustawa wprowadza standardy dostępu obywateli do akt, między innymi z jednej strony ograniczenia dla pracowników i tajnych współpracowników KGB, z drugiej - uprawnienia do utajnienia na wniosek ofiar i ich rodzin na okres do 25 lat danych dotyczących pochodzenia, poglądów i życia osobistego, stosowane nie wobec całych dokumentów, lecz jedynie poszczególnych informacji. Ustawodawcy przewidzieli także digitalizację zasobów i udostępnienie ich w internecie.

W końcu najszerszy zakres i potencjalnie najgłębsze skutki ma ustawa „O potępieniu komunistycznego i narodowosocjalistycznego (nazistowskiego) reżimów totalitarnych i zakazie propagowania ich symboliki" (Właściwa ustawa dekomunizacyjna 2015). Ustawodawcy powołali się na obowiązujące akty prawne, pochodzące $z$ dwu poprzednich okresów intensyfikacji ukraińskiej polityki wobec pamięci. W 1991 roku, niedługo przed proklamacją niepodległości państwa, w ustawie „O rehabilitacji ofiar represji politycznych na Ukrainie” potępiono nie reżim sowiecki czy ideologię komunistyczną, lecz same represje. Z kolei w 2006 roku w ustawie „O Hołodomorze w latach 1932-1933 na Ukrainie”, z inicjatywy prezydenta Juszczenki, uznano głód za zbrodnię ludobójstwa popełnioną przez kierownictwo ZSRR na narodzie ukraińskim, a zaprzeczanie, iż miał on miejsce, uznano za łamanie prawa. Jednak, podobnie jak w ustawie o „walczących o niezależność”, nie określono wymiaru kary i nie wprowadzono go do kodeksu karnego ${ }^{3}$.

Obecna ustawa idzie znacznie dalej niż te z lat 1991 i 2006, gdyż określa rządy sowieckie na Ukrainie w czasie całego okresu 1917-1991 jako zbrodnicze, stosując wobec nich ten sam termin co wobec rządów III Rzeszy z lat 1941-1944. Zakazuje propagandy obu tych reżimów, co ustawodawcy rozumieją jako: „publiczne zaprzeczanie, zwłaszcza poprzez środki masowej informacji” ich „zbrodniczemu charakterowi”, a także jako „usprawiedliwianie [...] działalności sowieckich organów bezpieczeństwa państwa [i] ustanowienia władzy sowieckiej na Ukrainie”, w końcu jako „wytwarzanie i/lub upowszechnianie oraz publiczne wykorzystanie produkcji, która zawiera symbolikę" komunistyczną lub nazistowską.

3 Ponadto w styczniu 2010 roku Sąd Apelacyjny Kijowa wydał wyrok stwierdzający odpowiedzialność ośmiu członków kierownictwa ZSRR i WKP(b), na czele ze Stalinem, za popełnienie tej zbrodni ludobójstwa. 
Do symboliki komunistycznej zaliczono: flagi, godła i hymny państwowe ZSRR i USRR oraz innych republik związkowych i państw komunistycznych w Europie, wyobrażenia zawierające symbole sierpa i młota, wszelkie znaki, którymi posługiwała się sowiecka partia komunistyczna, a także pomniki, tablice pamiątkowe i napisy poświęcone funkcjonariuszom partyjnym od szczebla sekretarza komitetu rejonowego, osobom pełniącym kierownicze funkcje we władzach centralnych ZSRR i USRR oraz w administracji obwodów i miast, w końcu wszystkim pracownikom organów bezpieczeństwa (zarówno odnoszące się do nich ogólnie, jak i sławiące poszczególne ich dokonania). Osobno zakazem upamiętnienia objęto działania skierowane przeciwko „walczącym o niepodległość” Ukrainy. Jednocześnie z ogółu wydarzeń wojennych z udziałem wojsk sowieckich w latach 1917-1991 spod zakazu wyłączono te, które polegały na stawianiu oporu, a następnie wyparciu z Ukrainy okupantów nazistowskich. Wyłączenie to dotyczy także upamiętnień działań oraz cytatów powstałych pod rządami sowieckimi, ale „powiązanych z rozwojem ukraińskiej kultury i nauki".

Następną kategorię objętą dekomunizacją stanowią wszystkie nazwy topograficzne od szczebla obwodów, rejonów, miast i wsi po ulice, skwery czy zaułki wewnątrz nich, a także nazwy wszystkich instytucji (szkoły, zakłady pracy) mające związek z ustanowieniem i obroną władzy sowieckiej. Wobec tych nazw także zastosowano wymienione dwa wyjątki - dotyczące walki przeciw III Rzeszy oraz narodowej kultury i nauki.

Katalog symboli reżimu nazistowskiego, znacznie zwięźlej opisany w ustawie, obejmuje te same kategorie, $z$ tą różnica, że nie zawiera żadnych wyłączeń. Dotyczy jedynie III Rzeszy, nie obejmuje natomiast symboli czy to innych ruchów i państw faszystowskich z lat trzydziestych-czterdziestych XX wieku (m.in. Włochy, Węgry), czy to ruchów współczesnych (neofaszystowskich).

$\mathrm{Z}$ zakazu wyłączono wytwarzanie i wykorzystanie symboliki obu reżimów dla celów muzealnych, w badaniach naukowych oraz w podręcznikach i innych materiałach dydaktycznych czy przy okazji rekonstruowania wydarzeń historycznych, pod warunkiem że nie prowadzi to do „zaprzeczenia” ich „zbrodniczego charakteru". Zgodzono się zostawić symbole komunistyczne umieszczone „na nagrobkach, pomnikach i znakach pamiątkowych znajdujących się na cmentarzach", a także będące w rękach prywatnych kolekcjonerów.

Zgodnie $z$ ustawą łamanie zakazu propagowania tych reżimów stanowi podstawę odmowy rejestracji przez Ministerstwo Sprawiedliwości organizacji społecznych i partii politycznych lub zakończenia ich działalności (co wyklucza istnienie Komunistycznej Partii Ukrainy), a w przypadku środków masowej informacji nieotrzymanie koncesji lub utratę praw wydawniczych czy emisyjnych. Organizacjom i partiom pozostającym $w$ konflikcie $z$ zakazami wprowadzonymi przez ustawę $\mathrm{w}$ chwili jej wejścia $\mathrm{w}$ życie przyznano jedynie jeden miesiąc na dostosowanie dokumentów, nazw i symboli, mediom - trzy miesiące, a właścicielom znaków towarów i usługodawcom - sześć miesięcy. Osobom ła- 
miącym zakaz propagandy zagrożono karą więzienia do lat 5 , a osobom, które dodatkowo: dopuszczą się tego po raz kolejny, są przedstawicielami władzy państwowej, działają w zorganizowanej grupie lub wykorzystują środki masowej informacji — od 5 do 10 lat (jednocześnie o te zapisy uzupełniono kodeks karny).

$\mathrm{Na}$ zmianę nazw wewnątrz miast i wsi oraz usunięcie pomników, tablic pamiątkowych i napisów radom samorządowym przyznano sześć miesięcy. Ustalono, iż $\mathrm{w}$ sytuacji niedopełnienia obowiązku zmiany zostaną wprowadzone $\mathrm{w}$ terminie trzymiesięcznym rozporządzeniami przewodniczących lokalnych władz wykonawczych odpowiednich szczebli. W ten sposób naruszono zasadę rozdzielności kompetencyjnej administracji samorządowej i rządowej. Gdyby jednak i ci urzędnicy pozostali bezczynni, w czasie kolejnych trzech miesięcy zmian mieli dokonać gubernatorzy obwodów, bezpośrednio podlegający prezydentowi. $Z$ kolei zmianę nazw samych miast i wsi oraz nazw rejonów i obwodów ${ }^{4}$ miały poprzedzić konsultacje społeczne, w ciągu sześciu miesięcy zorganizowane przez rady samorządowe odpowiednich szczebli. Następnie wyłonione $\mathrm{w}$ ten sposób propozycje miała zatwierdzić $\mathrm{w}$ głosowaniu RN po zasięgnięciu opinii UIPN. Gdyby rady nie dotrzymały tego terminu, ustawa upoważniła parlament do samodzielnej zmiany nazw.

Na przeprowadzenie dekomunizacji w zwykłym trybie przewidziano zatem sześć miesięcy — od 21 maja do 21 listopada 2015 r. Najprawdopodobniej nieprzypadkowo wybrano nie tylko datę uchwalenia ustaw, ale także końcowy termin wykonania najważniejszej z nich -21 listopada został wprowadzony przez prezydenta Poroszenkę do kalendarza świąt państwowych jako Dzień Godności i Wolności, aby upamiętnić datę początku rewolucji w 2013 roku.

\section{USTAWY W UKRAIŃSKICH MEDIACH}

Debata na temat ustaw odbyła się na forum internetowym dwumiesięcznika i wydawnictwa książkowego „Krytyka”, istniejącego od 1997 roku, z siedzibą w Kijowie. Ukraińsko-harwardzka proweniencja redaktorów ${ }^{5} \mathrm{w}$ dużej mierze tłumaczy pochodzenie idei przyświecającej jego założycielom — miało się ono

\footnotetext{
${ }^{4}$ Najpoważniejszym wyzwaniem była zmiana nazw miast stołecznych obwodów dniepropietrowskiego i kirowohradzkiego, gdyż pochodziły one od nazwisk bolszewików: Hryhorija Petrowskiego i Sergieja Kirowa. Powrót do nazw tych miast z czasów przedsowieckich (Dniepropietrowsk - Katerynoslaw, Kirowohrad - Jelizawetgrad) nie wchodził w grę, gdyż jako utworzone od imion władczyń Katarzyny II i Elżbiety I stanowiły one $z$ kolei symbole Imperium Rosyjskiego. UIPN policzył, że obowiązek zmiany nazwy własnej dotyczy 877 miast i wsi (Interaktywna karta mist $i$ sit, jaki majut" perejmenuwaty 2015). Natomiast liczba nazw ulic i instytucji przewidzianych do zmiany sięgała z pewnością dziesiątek tysięcy.

${ }^{5}$ Dwaj członkowie redakcji George Grabowicz (redaktor naczelny) i Serhii Plokhy są profesorami Harvard Ukrainian Research Institute (HURI), który jest częścią słynnej uczelni. Placówkę tę powołała ukraińska diaspora w Ameryce Północnej w 1973 roku. Wspiera ona finansowo także samą „Krytykę".
} 
stać na Ukrainie takim miejscem recenzowania książek i wymiany myśli, jak w USA „The New York Review of Books”. „Krytyka” walnie przyczyniła się do rozwoju refleksji teoretycznej nad postsowiecką rzeczywistością, a co za tym idzie - do ukonstytuowania pola intelektualnego Ukrainy. W osiemnaście lat od chwili powstania pozostaje medium, które za utrzymanie wysokiego poziomu publikacji „płaci” ograniczonym zakresem społecznego oddziaływania (mimo że od kilku lat przykłada dużą wagę do funkcjonowania w internecie i mediach społecznościowych). Jeśli osoby często publikujące na łamach „Krytyki" - wymienię tu tylko najbardziej znanych członków redakcji: Jurija Andruchowycza, Jarosława Hrycaka, Wołodymyra Kułyka czy Mykołę Riabczuka - chcą wpływać nie tylko na poglądy naukowców-humanistów czy twórców, ale także na przekonania opinii publicznej, muszą „schodzić” do mediów masowych i udzielać tam wywiadów czy prowadzić blogi.

Jeżeli chodzi o media masowe, to uwarunkowania własnościowe, polityczne i finansowe (niski stopień zamożności społeczeństwa i niewielka sprzedaż publikacji płatnych) ich funkcjonowania na Ukrainie są tak specyficzne, że żadne $z$ nich nie stało się forum jakościowej debaty nad sprawami publicznymi. Jak zauważa Ola Hnatiuk (zob. w tym numerze „KiS”), wynikło to z jednej strony $z$ faktycznego podporządkowania audiowizualnych mediów państwowych obozowi politycznemu pozostającemu właśnie przy władzy, z drugiej $-z$ utrzymywania prywatnych kanałów telewizji i tytułów prasowych przez oligarchów nie w celu realizacji misji publicznej ani nawet nie jako istotnego źródła dochodów (co byłoby ich główną motywacją, gdyby władza polityczna i wielki biznes były rozdzielone), lecz głównie jako reprezentacji ich interesów. Na Ukrainie nie powstały także ogólnokrajowe dzienniki opiniotwórcze. W kwietniu i maju 2015 roku kwestia dekomunizacji była w mediach poruszana najczęściej w formie zwracania uwagi na wynikające $z$ oczekiwanej zmiany nazw konsekwencje dla władz lokalnych i obywateli czy relacjonowania naprędce przeprowadzanych sond ulicznych.

W ukraińskiej telewizji i prasie drukowanej nie było miejsca na pogłębioną wymianę zdań na ten temat. Wynikało to nie tylko z ogólnej światowej tendencji do tabloidyzacji mediów. $Z$ jednej strony bowiem państwowy kanał telewizji Pierwszy Narodowy — koncentrował się na przekazywaniu informacji o działaniu państwa i rozjaśnianiu obywatelom polityki władz zgodnie $z$ ich intencjami. $Z$ drugiej strony oligarchiczni właściciele mediów prywatnych, takich jak kanały telewizyjne ISTV, STB, Nowyj i M1 oraz dziennik „Fakty” (Wiktor Pinczuk), kanał „1+1” i agencja informacyjna UNIAN (Ihor Kołomojski), kanał „Ukrajina” i dziennik „Siegodnia” (Rinat Achmetow) czy kanały „Inter” i „NTN” (Dmytro Firtasz i Serhij Lowoczkin), nie byli zainteresowani prowadzeniem dyskusji na tematy tak „poboczne” w stosunku do kwestii zachowania własnych pozycji w górnictwie, hutnictwie, przemyśle chemicznym, bankowości, telekomunikacji, handlu surowcami naturalnymi i energią elektryczną, jak... zmiany nazw na Ukrainie. 
Wymienieni właściciele mediów, z których informacje czerpie zdecydowana większość mieszkańców Ukrainy, reprezentowali różne nastawienia wobec władz wybranych w 2014 roku — od wprost wspierających ich politykę w konflikcie z Rosją (Kołomojski) po opozycyjne (Firtasz i Lowoczkin). To właśnie tym dwu ostatnim oligarchom poparcie oddolnego oporu wobec dekomunizacji, czy nawet rozniecenie go z pomocą własnych mediów, mogło być przydatne, na przykład w kampanii przed wyborami samorządowymi w październiku 2015 roku. Faktycznie kierowali oni w parlamencie Opozycyjnym Blokiem, ugrupowaniem powstałym w miejsce dawnej Partii Regionów Janukowycza, i pragnęli zachować wpływ na władze lokalne w obwodach wschodnich i południowych. Zatem ich podejście do dekomunizacji było czysto instrumentalne.

Również kanał informacyjny TV5, który od Pomarańczowej Rewolucji zawsze reprezentował orientację prodemokratyczną i proeuropejską, nie spełnia kryteriów medium niezależnego. Od powstania w 2003 roku należy do wielkiego przedsiębiorcy w branży cukierniczej... Petra Poroszenki, obecnie głowy państwa ukraińskiego.

W tej sytuacji na Ukrainie media dostępne za pośrednictwem internetu, niepaństwowe i nie należące do wymienionych osób: portale informacyjne, powstałe w ostatnich dwu latach stacje telewizji funkcjonujące poza systemem koncesji państwowych (Hromadske.tv, Espreso.tv), oraz niektóre dzienniki i periodyki (mające także wersje drukowane - gł. dziennik „Deń”, tygodniki: „Ukrajinśkyj tyżdeń” i „Dzerkało tyżnia”) odgrywają większą rolę w zachowaniu pluralizmu informacyjnego niż $\mathrm{w}$ innych państwach europejskich. Jednak między 9 kwietnia a 21 maja 2015 r. one także nie zaangażowały się w debatę nad ustawami. Od początku kształtowania się tego sektora mediów zdecydowaną przewagę $\mathrm{w}$ nim mieli zwolennicy demokratyzacji i orientacji proeuropejskiej na Ukrainie, często uczestnicy czy sympatycy obu rewolucji — w roku 2004 i 2013/2014. W ciągu półtora roku, jakie upłynęło od drugiej $z$ nich, stale „wypatrywali” oni ruchów reformatorskich po stronie władz. Ponieważ zakres i tempo reform były ostatnio coraz częściej krytykowane jako niewystarczające, ustawy przeważnie jawiły się im jako osiągnięcie rządzących — wprawdzie nie najważniejsze, ale jednak niezbędne ${ }^{6}$.

\section{DEBATA W „KRYTYCE”: GRANICE NIEPOROZUMIENIA}

Początkiem debaty w „Krytyce” była inicjatywa ukrainistów ze świata zachodniego, którzy zwrócili się do redakcji o opublikowanie listu otwartego (Widkrytyj list 2015). Zaapelowali $\mathrm{w}$ nim do prezydenta, aby nie podpisy-

\footnotetext{
${ }^{6}$ Niemal w ogóle nie podjął tematu dekomunizacji portal historyczny „Istoryczna Prawda”, związany z legendarnym portalem informacyjnym „Ukraińska Prawda”, założonym jeszcze w 2000 roku przez Georgija Gongadze.
} 
wał ustawy o „walczących o niepodległość” oraz właściwej dekomunizacyjnej, gdyż zawierają one zakazy głoszenia alternatywnych interpretacji przeszłości i stanowią ograniczenie dla wolności słowa i badań naukowych. W wypadku wejścia w życie tych aktów przewidzieli dwie negatywne konsekwencje: dużą stratę wizerunkową kraju w opinii światowej oraz pogłębienie podziału wewnętrznego i w konsekwencji wzrost zagrożenia bezpieczeństwa Ukrainy. Ich zdaniem ustawy wzmogą wśród obywateli na terytoriach okupowanych poczucie odepchnięcia przez Kijów, to zaś spowoduje zmniejszenie szans na pokojowe zakończenie konfliktu, zwiększy natomiast szeregi zwolenników Władimira Putina. W ich przekonaniu te dwie ustawy narzucają tak jednostronny obraz przeszłości na Ukrainie, że zwolennicy poglądu, iż zwycięstwo ZSRR nad III Rzeszą było wielkim osiągnięciem historycznym, poczują się zastraszeni. Uznanie OUN za organizację niepodległościową uznali za niewłaściwe ze względu na to, że obie jej frakcje w czasie wojny kolaborowały z III Rzeszą, a frakcja Bandery ponadto brała udział w pogromach Żydów w 1941 roku. Z kolei uznanie UPA podważyli, wskazując na zamordowanie Polaków na Wołyniu. Twierdzili, że właściwa ustawa dekomunizacyjna stanowi zagrożenie dla wolności badań między innymi dlatego, że uniemożliwia neutralne czy pozytywne sądy o takich etapach historii Ukrainy sowieckiej, jak z jednej strony okres ukrainizacji lat dwudziestych, $\mathrm{z}$ drugiej — pierestrojki w latach 1985-1991.

List podpisało 64 naukowców — humanistów reprezentujących wiele ośrodków naukowych Stanów Zjednoczonych, Kanady, Australii i Europy Zachodniej, w tym wywodzących się z Ukrainy. Wprawdzie nie było tam niektórych wybitnych znawców Europy Wschodniej (jak Timothy Snyder ${ }^{7}$ ), można jednak przyjąć, że w inicjatywie wzięła udział większość znanych badaczy zajmujących się Ukrainą w świecie zachodnim. Instytucje naukowe na Ukrainie reprezentowało wśród nich tylko pięć osób, wyłącznie należących do młodszego pokolenia. Nie było tam także ukrainistów z Polski i Rosji. Jakkolwiek są podstawy, by przypuszczać, że list podpisałoby wielu z nich, to jednak, o ile mi wiadomo, nie zabiegano o włączenie ich do tej inicjatywy. Wielu zajmujących się Ukrainą przedstawicieli polskiego i rosyjskiego pola akademickiego (przeważnie historyków) utrzymuje nie mniej intensywne kontakty $z$ ukraińskimi kolegami niż ukrainiści z państw świata zachodniego, jednak przeważnie nie uczestniczą oni w polu intelektualnym Ukrainy, powstałym przede wszystkim $z$ udziałem uczonych ukraińskich oraz zachodnich i koncentrującym się w dużej mierze właśnie wokół „Krytyki”. Pozostaje ono otwarte, są jednak dwa warunki pełnego w nim uczestnictwa: umiejętność dyskutowania w języku angielskim

\footnotetext{
${ }^{7}$ Jednak on także $\mathrm{w}$ dwóch punktach podzielił pogląd autorów listu: w kwestii straty wizerunkowej Ukrainy na arenie międzynarodowej oraz zagrożenia dla badań historycznych (Snyder 2015). Jednocześnie różnił się od wielu z nich mocnym podkreśleniem prawa Ukrainy do obrony przed rosyjską agresją, także propagandową, którą uważał za niebezpieczną dla całej Europy (Snyder 2014).
} 
(i przynajmniej biernej znajomości języka ukraińskiego) oraz zachowanie dystansu wobec sporów toczonych przez "narodowe" historiografie o wydarzenia $z$ dziejów Europy Wschodniej ${ }^{8}$. Pilnie strzegą swego wizerunku reprezentantów humanistyki niezaangażowanej zwłaszcza badacze reprezentujący kraje niezwiązane $\mathrm{w}$ przeszłości $\mathrm{z}$ konfliktami $\mathrm{w}$ tym regionie.

Podstawowym starciem, które nastąpiło na forum „Krytyki”, była wymiana zdań między Wołodymyrem Wjatrowyczem a historykiem z University of Alberta w Edmonton, autorem książek o polityce wobec pamięci współczesnej Ukrainy, Davidem R. Marplesem (2007). Przedstawię je w pierwszej kolejności, gdyż ich głosy można uznać za modelowo przeciwstawne i wyznaczające granice całej debaty.

Prezes UIPN przede wszystkim zaprezentował pogląd, iż ustawy stanowią nieodłączny element, a nawet więcej - warunek powodzenia demokratycznej transformacji, czego dowodzi doświadczenie państw postkomunistycznych będących już członkami UE. Jego zdaniem, ich niewprowadzenie umożliwiło „neosowiecki rewanż Janukowycza” w latach 2010-2014 oraz powodzenie agresji zbrojnej Rosji w Donbasie w 2014 roku, wspartej przez ludzi reprezentujących sowieckie wartości i obraz przeszłości. Zgodził się z autorami listu, iż ustawy dotyczą kwestii bezpieczeństwa Ukrainy, wyciągnął jednak z tego przeciwny wniosek: jedynie pełne zwalczenie reliktów sowieckości mogło uwolnić od „terrorystycznych bojówek” donieckiej i łuhańskiej „republiki ludowej”. Z kolei zarzut zignorowania przez rządzących stanowiska opozycji oddalił za pomocą argumentu, iż do Opozycyjnego Bloku wchodzą dziś ludzie dawnego reżimu Janukowycza, którzy popierając metody tłumienia Euromajdanu przez prezydenta, sami złamali zasadę wolności słowa. Wjatrowycz nie widział zagrożenia dla wolności badań naukowych, gdyż ustawa o walczących nie wprowadziła odpowiedzialności kryminalnej, a właściwa ustawa dekomunizacyjna wyłączyła je z zasady penalizacji.

Zawarte $\mathrm{w}$ liście otwartym przypisanie UPA masowych zbrodni Wjatrowycz uznał za jeden $z$ wielu poglądów wymagających dalszych badań naukowych. Przekonywał, iż ustawa o statusie walczących była niezbędna także dlatego, że - co pokazała rewolucja i wojna na Ukrainie w latach 2013-2014 - powstańczy folklor (czerwono-czarna flaga, pieśni UPA) był ważną częścią tożsamości narodowej Ukraińców. Wjatrowycz przywołał pogląd o pełnej ekwiwalentności zbrodni III Rzeszy i ZSRR. Następnie zarzucił grupie autorów listu

8 W Polsce osób stale zajmujących się Ukrainą i spełniających jednocześnie oba warunki nie ma tak wiele, jak mogłoby się wydawać. W konsekwencji polscy humaniści uczestniczą w polu intelektualnym Ukrainy z reguły jedynie w sprawach, które bezpośrednio dotyczą relacji między dwoma państwami: pojednania historycznego i eksperckiej pomocy w niektórych reformach ustrojowych. Z kolei w Rosji istnieje środowisko historyków, które te dwa warunki spełnia w całości - krąg kwartalnika „Ab Imperio” z Kazania. Jednak inaczej niż „Krytyka” jest to, po pierwsze, periodyk typowo akademicki, który, po drugie, zajmuje się Ukrainą jako jednym z wielu krajów należących do dawnego Imperium Rosyjskiego. 
niepodzielanie go, oddanie moralnej przewagi komunizmowi i w konsekwencji notoryczne, niezgodne $\mathrm{z}$ faktami, zaliczanie $\mathrm{w}$ ich pracach historycznych ukraińskich ugrupowań niepodległościowych w XX wieku do sił „kolaboracjonizmu” i „faszyzmu”. Zdaniem prezesa UIPN druga grupa autorów, skądinąd ludzi zasłużonych dla „odrodzenia Ukrainy i jej wolności”, stała się obiektem manipulacji pierwszej grupy. Ostatecznie, konkludował, list stał się instrumentem w wojnie propagandowej prowadzonej dziś przez Rosję przeciw Ukrainie (Wjatrowycz 2015c).

Większość argumentów Wjatrowycza została podważona przez uczestników debaty. Wydaje się jednak, iż w jednym miał on słuszność. Zarzut o zastraszeniu reprezentantów pamięci o zwycięstwie w Wielkiej Wojnie Ojczyźnianej nie był trafny. Ustawa o drugiej wojnie światowej oddawała cześć żołnierzom sowieckim i wprowadzała porządek dni pamięci służący wewnętrznemu pojednaniu. Autorzy listu skoncentrowali się na negatywnych konsekwencjach ustaw, nie wskazując w ogóle elementów pozytywnych — i tego właśnie, i samej zasady otwarcia archiwów.

W odpowiedzi Marples (2015) uznał, iż autorzy listu nie mogą ponosić odpowiedzialności za to, że propaganda rosyjska wykorzystuje ich prace historyczne czy obecne stanowisko. Rozwinął przede wszystkim trzy argumenty. Po pierwsze, ustawa o walczących zagraża wolności słowa, gdyż pozostawia szeroką sferę niejasności, jakie wypowiedzi na temat zawartych w niej organizacji mogą być traktowane jako przestępstwo. Nie precyzuje, co miałoby być kwalifikowane jako „zaprzeczanie faktu legalności” i „obraza” walczących o niezależność. Dodał, iż złe praktyki na Ukrainie już się zaczęły — władze naciskają na historyków, aby nie wypowiadali się o nacjonalistycznej ideologii OUN i zbrodniach UPA, skądinąd mających status stwierdzonych faktów, a nie opinii pojedynczych badaczy.

Po drugie, uwagi Wjatrowycza na temat mieszkańców okupowanej części Donbasu oraz opozycji wobec obecnego rządu Marples uznał za wyraz nacjonalistycznego rozumienia tożsamości narodowej, które pozbawia ich prawa do uczestnictwa we wspólnocie jako niespełniających kryteriów „prawdziwej ukraińskości”. Odrzucił też pogląd o autentycznym zakorzenieniu „banderowskich" symboli w pamięci i kulturze Ukraińców. Przeciwstawił mu pogląd, iż ludzie w czasie wojny potrzebują symboli wyrażających nastroje sprzeciwu, jednak często nie wiedzą, jakie idee głosili i jak postępowali w przeszłości ci, do których one się odnoszą. Zasugerował, iż to właśnie bałamutne wyjaśnienia ludzi ukrywających część historii OUN i UPA przyczyniają się do tego, że społeczeństwo ukraińskie nie ma rzetelnej wiedzy o przeszłości.

Po trzecie, Marples stwierdził, iż nie będzie spierał się z adwersarzem co do ekwiwalentności zbrodni reżimu nazistowskiego i stalinowskiego, reprezentuje natomiast dwa poglądy: o unikalności Holokaustu w historii oraz o tym, iż dziedzictwo ZSRR jest wewnętrznie sprzeczne. Aby dowieść drugiej z tych tez, wymienił przykłady „dobrych” komunistów: przywódców tzw. narodowego 
bolszewizmu na Ukrainie w latach dwudziestych oraz lidera USRR $z$ lat sześćdziesiątych Petro Szełesta (zamordowanych lub usuniętych ze stanowisk przez władze ZSRR w Moskwie). W związku z tym argumentowal, iż państwo nie powinno odrzucać wszystkich postaci i zjawisk po stronie władz USRR w latach 1917-1991. Jego zdaniem zakazy, kary czy usunięcie pomników nie mogą zmienić przekonań ludzi — można to osiągnąć jedynie przekonując ich w toku dyskusji (Marples 2015).

Marples pokazał, iż sposób myślenia Wjatrowycza wynika z traktowania obrazów przeszłości jako środka służącego państwu do mobilizacji politycznej obywateli, a także $z$ wiary w skuteczność kształtowania tożsamości za pomocą środków administracyjnych. Jednak w jednym punkcie zarysowane przez niego analogie historyczne pomijały wrażliwość Ukraińców, przyczyniając się do narastania nieporozumienia. Aby wskazać przykłady właściwych strategii w postępowaniu $z$ „ciemnymi plamami” w historii, przywołał to, jak z odpowiedzialnością za kolonializm i wyniszczenie autochtonów zmierzyły się Wielka Brytania, Kanada i Stany Zjednoczone (w tym przypadku także za wojnę w Wietnamie), a w końcu fakt wyznania winy za Holokaust przez Niemcy. Jednocześnie zasugerował, iż odmowa uznania zbrodni UPA przez Ukrainę stawia ją w jednym rzędzie z Turcją, która odrzuca kwalifikację ludobójczą zbrodni na Ormianach w latach 1915-1916. Jednak zgodnie $z$ szeroko na Ukrainie wyznawanym poglądem, kraj ów był jednym z największych przegranych historii XX wieku, podczas gdy wymienione państwa (z wyjątkiem Niemiec) w dużej mierze właśnie dzięki prowadzeniu takich działań zbudowały swą współczesną pozycję i dobrobyt. Głębokie poczucie deprywacji, przekonanie o byciu samemu ofiarą zbrodni masowych XX wieku i brak satysfakcji z rozwoju kraju po 1991 roku sprzyjały temu, że reprezentowany przez Marplesa i innych autorów listu dyskurs wartości uniwersalnych był na Ukrainie, podobnie jak w innych częściach świata przekonanych o swojej peryferyjności, utożsamiany $z$ dominacją Zachodu i odrzucany.

\section{DYSKURS NARODOWO-LIBERALNY}

Głosy pozostałych uczestników dyskusji na forum „Krytyki”, którzy (z jednym wyjątkiem) wspomnianego listu nie podpisali, można, dokonawszy pewnych uproszczeń, zinterpretować jako reprezentatywne dla trzech dyskursów. Dwa $z$ nich miały charakter bardziej ogólny: narodowo-liberalny oraz dekonstruktywistyczny, trzeci - ekspercki - powstał z odwołaniem do praw człowieka i doświadczeń dekomunizacyjnych innych krajów Europy Srodkowej. W dalszej analizie przywołuję też głosy kilku osób, które wprawdzie wypowiedziały się na innych forach niż „Krytyka”, jednak cieszą się ugruntowaną pozycją w życiu intelektualnym Ukrainy.

Reprezentanci dyskursu narodowo-liberalnego opierali się na trzech przekonaniach. Po pierwsze, ustawy stanowią odpowiedź władz na autentyczną, 
wyrażoną w czasie rewolucji, odczuwaną przez przytłaczającą większość społeczeństwa potrzebę odzyskania poczucia narodowej godności i dumy z własnej historii. Po drugie, naczelną zasadą jest wolność słowa, jednak odstępstwa od niej mogą następować w przypadku prowadzenia wojny obronnej. Po trzecie, część autorów listu do prezydenta powiela tezy sowieckich historyków o Ukrainie.

Za podstawowe kryterium oceny Alexander Motyl, historyk z Rutgers University w Newark, uznał odpowiedź na pytanie, czy ustawy sprzyjają sprawiedliwości i wolności. Jego zdaniem, bilans był zdecydowanie pozytywny. Ustawa o „walczących o niepodległość”, odwracając tezy „sowieckiej, rosyjskiej i neosowieckiej propagandy" na ich temat, przyczyni się do przełamania hegemonii „rasizmu i neokolonializmu” w odniesieniu do Ukrainy i przywróci Ukraińcom prawo tworzenia własnej interpretacji historii (podobnie jak Afroamerykanom czy kobietom, w związku ze zmianą zachodzącą w historiografii światowej). Jednak zakaz głoszenia alternatywnych ocen walczących o niepodległość, zdaniem Motyla, sięgał zbyt daleko - powinien dotyczyć tylko dawnego, odrodzonego dziś przez Putina, dyskursu sowieckiego o ukraińskim ruchu niepodległościowym, a nie wszystkich wypowiedzi krytycznych. W jego przekonaniu właściwa ustawa dekomunizacyjna miała wzmocnić sprawiedliwość poprzez zadośćuczynienie ofiarom komunizmu, a jednocześnie $\mathrm{w}$ tym sensie dochowywała zasady wolności, że zakazywała jedynie używania symboli reżimów totalitarnych, a nie poglądów komunistycznych i nazistowskich jako takich. W polemice $z$ autorami listu Motyl odwrócił ich zarzuty - uznał, iż to właśnie oni, wyznając neosowieckie schematy, boją się pełnej wolności słowa na Ukrainie (Motyl 2015).

Z kolei Mykoła Riabczuk (2015), publicysta i badacz społeczeństwa obywatelskiego oraz tożsamości narodowej, najdobitniej dał wyraz przekonaniu, iż całość przemian lat 2014-2015 na Ukrainie oznacza jej zerwanie ze stanem postkolonialnej zależności od Rosji. Jego zdaniem, autorzy ustaw słusznie przewidzieli pełne usunięcie symboli panowania ZSRR na Ukrainie, powinni jednak pójść dalej - w kierunku całkowitej dekolonizacji i objąć tą regulacją także symbole Imperium Rosyjskiego (np. ulice gen. Aleksandra Suworowa). Odnośnie do OUN i UPA Riabczuk przekonywał, iż uznanie ich roli w walce o niepodległość nie oznacza opuszczenia zasłony milczenia na ich zbrodnie. Zasugerował, iż zostały one popełnione $w$ ramach walki antykolonialnej, powinny być zatem oceniane $\mathrm{w}$ podobny sposób jak zbrodnie innych organizacji narodowowyzwoleńczych na świecie, jak Afrykański Kongres Narodowy w RPA, Front Wyzwolenia Palestyny czy izraelski Irgun i Lehi w latach czterdziestych na Bliskim Wschodzie.

Zdaniem Riabczuka, zachodnie media w inny sposób komentowały obalanie pomników Lenina przez Polaków, Czechów i Węgrów w 1989 roku niż przez Ukraińców, w 25 lat później. Wyrazem stosowania podwójnych standardów było, twierdził, przypisywanie pierwszym $z$ nich nastawien demokratycznych i antytotalitarnych, drugim - antyrosyjskich i ksenofobicznych. Zachód, są- 
dził ów intelektualista, podświadomie akceptował prawo Rosji do kontroli nad całym terytorium dawnego imperium. Skutkowało to wykluczeniem dyskursywnym i instytucjonalnym Ukraińców jako "gorszych” i wiązało się z niewyrażanym wprost brakiem zgody na przyjęcie ich kraju do UE i NATO.

Wyrazem dyskursu uprzedzenia do „Wschodu” i powielania tez sowieckiej propagandy był, zdaniem Riabczuka, między innymi list zachodnich ukrainistów. Opowiedział się on przeciwko penalizowaniu zaprzeczenia jakichkolwiek zbrodni w historii - tak Holokaustu, jak Hołodomoru - jakkolwiek uznał je za naganne moralnie. Część autorów listu reprezentowała kraje, w których zakaz zaprzeczania istnienia Holokaustu wprowadzono. Riabczuk pytał zatem: dlaczego nie protestowali przeciw temu, a dziś protestują przeciw zagrożeniu wolności słowa na Ukrainie? Jednocześnie starał się uzasadnić zakazy posługiwania się symboliką reżimu komunistycznego wprowadzone przez ustawy uznał, że będą obowiązywały w czasie wojny jako forma obrony Ukrainy.

Jednocześnie ten, skądinąd zawsze surowy, recenzent współczesnego państwa ukraińskiego i jego elit, uznał za trafny argument obrońców praw człowieka, iż ustawy zostały napisane w sposób nieprofesjonalny (zob. dalej). Ostatecznie ocenił, iż w tym momencie historycznym były one jak najbardziej potrzebne, zostały natomiast źle przygotowane.

Na koniec stanowisko Wołodymyra Kułyka (2015), politologa i medioznawcy z Narodowej Akademii Nauk Ukrainy, można zinterpretować jako bliższe reprezentantom dyskursu dekonstruktywistycznego. Zgodził się on między innymi z nimi, iż właściwa ustawa dekomunizacyjna sama podważa intencje swych twórców, gdyż jest wyrazem sowieckiej praktyki centralnego ustanawiania jednego modelu pamięci dla wszystkich części kraju. Skupił się na polemice $z$ autorami listu, choć nie podzielał wysuwanego wobec nich zarzutu, iż kierowali się nieuczciwymi motywami czy współdziałali z wrogami Ukrainy. Wytknął im dwa błędy - po pierwsze, nieuznawanie, iż członkowie OUN i UPA rzeczywiście walczyli o niezależność Ukrainy. Argumentował, iż zachodni historycy nie mają prawa pozbawiać dziś narodu ukraińskiego prawa do posiadania swoich bohaterów.

Po drugie, Kułyk utrzymywał, iż autorzy listu w rzeczywistości nie podzielają poglądu o jednakowej zbrodniczości komunizmu i nazizmu, wskutek czego na współczesnej Ukrainie spostrzegają jedynie te zagrożenia, które pojawiają się na skrajnie prawej części spektrum politycznego. Obecnie, argumentował, przestrzegają oni przed rozwojem popularności nacjonalistycznej partii Swoboda (między innymi właśnie $z$ jej wpływem wiążą wyrażony w ustawach stosunek do OUN i UPA), w ogóle nie protestowali natomiast przed rewolucją 2013/2014 roku ani przeciw wprowadzaniu przez reżim Janukowycza „neosowieckiej” interpretacji historii Ukrainy, ani przeciw głoszeniu „neoimperialnej” narracji przez ukraińskich komunistów.

W konkluzji Kułyk uznał ustawy za jakościowo słabe i nie spełniające standardów europejskich. Przychylił się do pomysłu zawetowania ich przez prezy- 
denta, jednak inaczej niż autorzy listu opowiedział się za wskazaniem przez niego poprawek i ponownym rozpoczęciem procesu ustawodawczego ${ }^{9}$.

Przedstawiciele dyskursu narodowo-liberalnego, podobnie jak Wjatrowycz, przekonaniu swych zagranicznych oponentów, iż pamięć zbiorowa jest konstruowana, przeciwstawiali pogląd o jej autentyczności. Łączyło ich także z nim postrzeganie rewolucji jako zrzucenia przez Ukrainę zależności kolonialnej czy postkolonialnej. Przy tym stali oni jednak na gruncie ochrony wolności słowa (Riabczuk - w wersji „amerykańskiej”), w niektórych rozwiązaniach w ustawach dostrzegali zatem zagrożenia. Podobnie jak reprezentanci wielu dyskursów grup zniewolonych na świecie w XX wieku poszukiwali uzasadnień dla przełamania przewagi dyskursu dominującego, nie wyrzekając się wartości liberalnych. I podobnie jak ich poprzednicy na tej drodze nie znaleźli, jak sądzę, przekonującego rozwiązania.

\section{DYSKURS DEKONSTRUKTYWISTYCZNY}

Reprezentanci dyskursu dekonstruktywistycznego doceniali znaczenie rewolucji jako momentu otwierającego nowy rozdział w kształtowaniu państwa obywatelskiego na Ukrainie i w związku z tym przeważnie nie odmawiali jej prawa do usunięcia symboli reżimów totalitarnych. Jednak za równie ważne uważali prowadzenie pracy nad pamięcią o przeszłości pod rządami sowieckimi i nazistowskimi w takim kierunku, aby mieszkańcy kraju spostrzegli, iż wiele negatywnych zjawisk z okresu 1917-1991 (od korupcji po zbrodnie masowe) było wynikiem nie tylko zewnętrznego panowania, ale także zinternalizowania przez ludność ideologii reżimów totalitarnych i/lub wpływu wcześniejszych przekonań i praktyk społecznych. Konsekwentnie bronili także prawa historyków do stwarzania różnych obrazów i wyciągania różnych wniosków na temat przeszłości.

Mychajło Hauchman (2015), młody historyk, absolwent Uniwersytetu w Łuhańsku, od wybuchu wojny przebywający w Ufie (Rosja), wyszedł od rozróżnienia pojęć dekomunizacji i desowietyzacji (deradianizacija). U źródeł pierwszej, jego zdaniem, leżało założenie, iż komunizm był systemem narzuconym Ukrainie. Dekomunizację, dowodził, przeprowadzano w niej już dwukrotnie: w latach 1990-1991, gdy odrzucono ideologię komunistyczną oraz od 2014 roku, gdy postanowiono wyzwolić się od mitów Wielkiej Wojny Ojczyźnianej i ZSRR. Takie postępowanie wynikało z przyjęcia na Ukrainie paradygmatu totalitaryzmu, zgodnie z którym społeczeństwo ZSRR postrzega się jako oddzielone od władzy, w konsekwencji — przedmiotem zainteresowania nie jest to, w jakim stopniu uczestniczyło ono czynnie w oficjalnych praktykach, czym podtrzymywało reżim. Zdaniem Hauhmana na Ukrainie nigdy nie podjęto

${ }^{9}$ Natomiast zdecydowanie za podpisaniem ustaw wypowiedział się ostatni z reprezentantów dyskursu narodowo-liberalnego w redakcji „Krytyki” Jurij Andruchowycz (2015). 
natomiast, znacznie potrzebniejszej, desowietyzacji. Zwolennicy desowietyzacji, opierając się na przekonaniu, że komunizm - inaczej niż nazizm - był w dużej mierze „swój”, powinni - argumentował historyk — odpowiedzieć na dwa pytania: co z przeszłości sowieckiej na Ukrainie odrzucić, a co zostawić? i, w związku z poprzednim, jak pozbawić Rosję monopolu na rozporządzanie dziedzictwem ZSRR?

Odnośnie do właściwej ustawy dekomunizacyjnej autor ów sądził, iż nie trafia w sedno, gdyż zakazuje propagandy i symboliki komunizmu i nazizmu, podczas gdy powinna zakazać tych elementów ich ideologii, które zakładały nienawiść wobec pewnych kategorii ludzi i, niezależnie od dwu wymienionych, występowały także w innych ideologiach nowoczesności. Ustawę o „walczących o niepodległość" uznał za wyraz ideologicznego podejścia do historii, ponieważ jej twórcy założyli, iż opór antybolszewicki był osią całej historii Ukrainy w okresie 1920-1991, a także pominęli fakt popełnienia przez UPA czystki etnicznej na Polakach.

Z kolei historyk Andrij Portnow, wywodzący się z Dniepropietrowska, obecnie wykładowca Uniwersytetu Humboldta, przestrzegał przed dalszym rozwojem na Ukrainie tendencji do etnicyzacji historii, czego wyrazem było z jednej strony pomijanie czy usprawiedliwienie zbrodni UPA na Polakach, z drugiej utożsamianie pozytywnych aspektów marszu Armii Czerwonej w latach 1944-1945 z Ukraińcami (np. wyzwolenie Auschwitz), negatywnych zaś - wyłącznie $z$ Rosjanami (np. gwałty na niemieckich kobietach). Uznał, iż na Ukrainie publicznie prawie nie występuje krytyka nacjonalizmu integralnego z pozycji demokratyczno-pluralistycznych, lecz jedynie w ramach dyskursu o Wielkiej Wojnie Ojczyźnianej (Portnow 2015a). Autor ten wykazał także, że przewidziany przez projektodawców katalog form podtrzymywania przez państwo pamięci o drugiej wojnie światowej był bliźniaczo podobny do form praktykowanych przed rokiem 1991 w odniesieniu do Wielkiej Wojny Ojczyźnianej.

Zdaniem Portnowa, projektodawcy reprezentowali esencjonalne rozumienie narodu jako grupy etnicznej, mającej stałą strukturę wewnętrzną i osnowę duchową, ukształtowanej przed wiekami i jako taka właśnie od roku 1917 wystawionej na niszczycielskie działania ZSRR. Wierzyli, sądził, w historię „obiektywną" i w rolę państwa w „przywróceniu” jedynego obrazu przeszłości. W jego ujęciu Wjatrowycz, głosząc pogląd o kluczowym znaczeniu polityki wobec pamięci $\mathrm{w}$ procesie demokratyzacji kraju, pogłębiał różnice tożsamościowe ludności po obu stronach frontu od wiosny 2014 roku rozdzielającego Donbas. Przywołując zdumiewająco proste uzasadnienia poszczególnych rozwiązań zawarte w ustawach (np. nieotwarcie archiwów do 2014 roku miało sprzyjać zachowaniu sowieckiej tożsamości ludności Krymu, a w konsekwencji - przyczynić się do jego aneksji przez Rosję), historyk ów unaocznił sposób postrzegania obecnego konfliktu przez członków kierownictwa UIPN. Ich zdaniem, twierdził, była to wojna tożsamości czy nawet cywilizacji. On sam sądził, iż konflikt nastąpił w wyniku oddziaływania dwu innych czynników: gry lokal- 
nych elit na uzyskanie autonomii w stosunku do Kijowa oraz interwencji Rosji na Ukrainie.

Ostatecznie, zauważył Portnow, ustawy dekomunizacyjne spychały Ukraińców na powrót w stronę sytuacji, w której byli już w latach 2010-2014, gdy rządy Janukowycza podobnie (tyle że działając z przeciwnego końca spektrum ideologicznego) tak „ustawiały” ukraińską debatę, aby obywatele mieli wybór tylko między dwiema modelowymi, wzajemnie przeciwstawnymi tożsamościami - „galicyjską" i „donbaską”. Z takiego punktu widzenia, konkludował, ustawy były zaprzeczeniem idei Euromajdanu, którego uczestnicy, bez względu na dzielące ich różnice tożsamościowe, wypracowali sprawnie działającą formułę narodu obywatelskiego (Portnow 2015b).

Dyskurs dekonstruktywistyczny reprezentował także członek redakcji „Krytyki”, najbardziej znany współcześnie na świecie historyk ze Lwowa Jarosław Hrycak. Bronił on ustawy o drugiej wojnie światowej ze względu na sprzyjanie wewnętrznemu pojednaniu pamięci, a także wprowadzenie historii Ukrainy $\mathrm{w}$ europejski kontekst. Pozostałe ustawy wywołały jego wątpliwości czy nawet sprzeciw. Hrycak ocenił, iż w obecnej sytuacji Ukrainy są one „krokiem w bok". Ich przyjęcie miałoby sens, gdyby zostało poprzedzone przez fundamentalne reformy ustrojowe i gospodarcze, na przykład utworzenie niezawisłego sądownictwa czy deregulację gospodarki. Tak, jego zdaniem, było w Polsce i w państwach bałtyckich, gdzie rozwiązania dekomunizacyjne (np. ustawy lustracyjne) wprowadzono w ponad dziesięć lat po rozpoczęciu transformacji. W obecnej sytuacji Ukrainy mogą się one przyczynić do rozpalenia kolejnego konfliktu wewnętrznego. Przekonywał, iż usunięcie pomników Lenina (nie we wszystkich regionach akceptowane) czy ufundowanie pomników Bandery ( $w$ wielu regionach odrzucane, gdyż poza Zachodem Ukrainy postać ta nie stanowi symbolu walki niepodległościowej) pozostanie sprawą do rozstrzygnięcia w przyszłości, zgodnie w wolą ludności poszczególnych części kraju. Zdaniem Hrycaka, obecnie na przeszkodzie modernizacji kraju w największym stopniu stoi „postsowiecka” mentalność Ukraińców. Skłania ona ludzi do pozostawania w ramach wąskich horyzontów intelektualnych i środowisk społecznych, a w konsekwencji przeciwdziała ich obywatelskiej aktywizacji (historyk określił to zjawisko mianem „lumpenizacji”). Parafrazując Lenina, który zdefiniował komunizm, używając hasła „władza radziecka plus elektryfikacja”, Hrycak ujął dekomunizację jako program streszczający się w słowach „demokratyzacja minus lumpenizacja" (Hrycak 2015).

Taka ocena ustaw koresponduje z prezentowaną przez Hrycaka od dawna $\mathrm{w}$ debacie propozycją, by w formułowaniu strategii rozwoju Ukrainy zaczęto w końcu myśleć opierając się na wartościach, nie zaś na wyprowadzanych z historii przeciwstawnych koncepcjach tożsamościowych. W wydanej około rok przed wprowadzeniem ustaw książce poświęcił on uwagę nieprzystawalności do sytuacji Ukrainy zachodnioeuropejskich modeli postępowania z przeszłością: hiszpańskiego (pakt milczenia i nierozliczenie zbrodni żadnej ze 
stron konfliktu z okresu 1936-1975), niemieckiego (przezwyciężenie „ciemnych" stron historii z lat 1933-1945) i anglosaskiego (uznanie racji obydwu stron dawnych konfliktów - na przykład w Wielkiej Brytanii w rewolucji w XVII wieku). Jego zdaniem, Ukraina przechodzi przez „zmieszane” doświadczenia hiszpańskie i niemieckie, choć nie gaśnie nadzieja, że w odległej przyszłości osiągnie model anglosaski. W każdym razie jej szanse rozwojowe są i będą zależne nie od jednoznacznej polityki tożsamości, lecz od konsekwentnego wprowadzania modernizacyjnych wartości europejskich (Hrycak 2014, s. $102-117)^{10}$.

W końcu dyskurs dekonstruktywistyczny reprezentowała także wywodząca się z Dniepropietrowska, pracująca w Tufts University w Medford, politolożka Oksana Shevel (2015). Wydobyła ona niezgodności między stanem wprowadzonym przez ustawy a standardami polityki wobec pamięci zawartymi w dokumentach europejskich instytucji integracyjnych (na które ogólnikowo powołali się projektodawcy). Rezolucje zgromadzeń parlamentarnych Rady Europy z 24 stycznia 2006 r. i Organizacji Bezpieczeństwa i Współpracy w Europie z 20 października 2009 r. nie zakazują głoszenia odmiennych poglądów - przeciwnie, chronią prawo prowadzenia wolnych debat jako drogę do zbudowania wiarygodnego obrazu przeszłości. Ponadto pierwsza z nich wzywa do osądzenia zbrodni komunistycznych, idzie w niej wszakże o konkretne działania władz (za które odpowiadały konkretne osoby), nie zaś o „zbrodniczy charakter” reżimu. Z kolei rezolucja RE z 29 stycznia 2009 r. nie rekomenduje demontażu całości symboli komunistycznych, wzywa natomiast do prowadzenia dialogu nad ich przyszłymi losami, zarówno na szczeblu wewnętrznym, z udziałem historyków, ekspertów i zainteresowanych wspólnot, jak i międzynarodowym. W końcu rezolucja tej organizacji z 27 czerwca 1996 r. wprowadza rozumienie dziedzictwa komunistycznego przede wszystkim nie jako pomników czy nazw miast lub ulic, lecz jako pozostałości zbiurokratyzowanych i zmilitaryzowanych struktur państwa, ma na myśli także „totalitarne modele myślenia”, jak kolektywizm, konformizm czy ślepe posłuszeństwo władzy.

Zdaniem Shevel zakazy i sankcje powinny być zatem $z$ ustaw usunięte, a czas przewidziany na przemianowanie nazw wydłużony, aby mogli w nim uczestniczyć członkowie wspólnot lokalnych. Autorka wskazała także na niezgod-

10 Trzeba jednak zauważyć, iż zdania historyków zajmujących się wiekiem XX w debacie były podzielone. Pogląd o zbędności regulacji historii przez parlament reprezentował Ołeksandr Zajcew z Ukraińskiego Uniwersytetu Katolickiego we Lwowie, znawca historii OUN (ustawy jako akt „interwencji hegemonii” władzy; szkodliwy zakaz emisji dzieł niemal całego kina radzieckiego; zbrodniczość ZSRR równa III Rzeszy dotyczyła tylko okresu stalinowskiego, czyli lat 1929-1953) (Zajcew 2015). Na negatywne konsekwencje upraszczania historii w ustawach zwrócili uwagę także dwaj młodzi historycy: Serhij Łunin z Charkowa (odnośnie do rewolucji 1917-1921; Łunin 2015) i Hryhorij Starykow z Kijowa, jednak ostatecznie widzieli potrzebę ich obowiązywania. Ten drugi argumentował nawet, że gdyby skierowanie ustaw do RN poprzedziła debata publiczna, to w ogóle by ich nie uchwalono (Starykow 2015). 
ność między zawartą w wymienionych dokumentach europejskich orientacją przede wszystkim na ochronę pamięci o cywilnych ofiarach zbrodni a widoczną w ustawie o walczących o niepodległość preferencją dla pamięci o bohaterach, z których część jednak takie właśnie zbrodnie popełniła. W jej przekonaniu państwo ukraińskie brnęło dalej w błędnym kierunku, zapoczątkowanym jeszcze przyjęciem ustawy z 22 października 1993 r. „O statusie weteranów wojny i gwarancjach ich ochrony socjalnej”. Uprawnienia kombatanckie otrzymali wtedy wszyscy, którzy walczyli po stronie ZSRR, bez względu na to, czy popełnili zbrodnie na cywilach. Obok żołnierzy Armii Czerwonej i partyzantów sowieckich dołączono do nich wtedy także członków UPA, ale tylko tych, którzy nie walczyli przeciw ZSRR po 1944 roku i nie dopuścili się takich zbrodni. Rozwiązanie to $z$ powodów ideologicznych preferowało stronę sowiecką $\mathrm{w}$ konflikcie z lat 1939-1953, dyskryminując stronę niepodległościową, a ponadto prowadziło do stosowania podwójnych standardów, gdyż wyłączało spod odpowiedzialności karnej reprezentantów tylko pierwszej z nich. Shevel wskazała, iż ustawa o „walczących o niepodległość” zrównała te dwie strony. Jednak nie tylko w kwestii uznania równorzędności ich racji, lecz niestety także w postaci wyłączenia $z$ poniesienia odpowiedzialności za zbrodnie. Jedynym słusznym wyjściem $z$ tej sytuacji była, jej zdaniem, nowelizacja obu tych ustaw uzależniająca przyznanie statusu weterana sowieckiego lub „walczącego o niepodległość" od niepopełnienia czynów karalnych (Shevel 2015).

Przedstawiciele dyskursu dekonstruktywistycznego podzielali większość zastrzeżeń i krytyk autorów listu do prezydenta. Jednak w zdecydowanie głębszy sposób niż oni pokazali, na czym polegają wynikające z implementacji ustaw zagrożenia dla procesu demokratyzacji i modernizacji Ukrainy oraz idei rewolucji 2013/2014 roku. Ponadto osiągnęli ten efekt bez uciekania się do argumentów, które wśród ukraińskiej opinii publicznej wywoływały poczucie bycia dyskryminowanymi przez reprezentantów dyskursu hegemonicznego.

\section{DYSKURS EKSPERCKI}

Eksperckie podejście obrońców praw człowieka zaowocowało wskazaniem wielu błędów prawnych popełnionych przez autorów ustaw. Natomiast z reguły nie podejmowali oni kwestii negatywnych skutków społecznych i politycznych w wypadku ich wprowadzenia ${ }^{11}$. W imieniu Charkowskiej Grupy Obrony Praw Człowieka, zasłużonej organizacji zajmującej się tą problematyka, kierowanej przez dawnego dysydenta Jewhena Zacharowa, analizę właściwej ustawy dekomunizacyjnej przedstawił Wołodymyr Jaworski. Wykazał on, iż mimo z pozoru sporej szczegółowości katalog zakazanych symboli nie jest

11 Wyjątek stanowiła Hala Kojnasz (2015), pedagożka, publicystka z Gdańska, która zarzuciła UIPN i obozowi rządzącemu prowadzenie modelowo sowieckiej polityki narzucania jednej ideologii, co antagonizuje opinię publiczną i zagraża bezpieczeństwu kraju. 
dość wyczerpujący, aby z całkowitą pewnością można było stwierdzić, których $z$ nich nie wolno używać. Ukazał niezgodność $z$ faktami zapewnień kierownictwa UIPN o powszechności obowiązywania w krajach Europy Środkowej stanu prawnego wprowadzanego właśnie na Ukrainie. Na podstawie wyroków Europejskiego Trybunału Praw Człowieka (ETPC) w sprawach przeciwko Węgrom oraz wyroków trybunałów konstytucyjnych Czechosłowacji, Polski, Węgier i Mołdowy udowodnił, iż przepisy o zakazie używania symboliki komunistycznej były w nich stosowane $z$ nadużyciem prawa. Ostatecznie zostały one uchylone, czy to właśnie z powodu braku precyzyjnych sformułowań, czy to uznania przez sądy, iż wymienione symbole odnoszą się do czegoś więcej niż reżim komunistyczny ${ }^{12}$.

Ponadto zdaniem Jaworskiego nie można było w ustawie utrzymać zakazu pokazywania olbrzymiej większości sowieckiej twórczości literackiej i audiowizualnej czy głoszenia alternatywnych naukowych interpretacji przeszłości pod zarzutem, iż pochwalają one reżim totalitarny. Rozstrzyganie przez sąd, które $z$ tych utworów czy wypowiedzi naukowców spełniają kryteria zawartych w ustawie stwierdzeń ocennych („stwarzają pozytywny obraz”, „usprawiedliwiają”, „zaprzeczają zbrodniczemu charakterowi reżimu”), było nie tylko bardzo trudne, ale także nie znajdowało podstawy $\mathrm{w}$ prawie międzynarodowym. W przeciwieństwie do zbrodni nazistowskich, na czele $z$ Holokaustem, które w wyroku Trybunału Norymberskiego uznano za dzieło przestępczych instytucji kierowniczych III Rzeszy, zbrodnie komunistyczne nie były osądzone. W tej sytuacji $\mathrm{w}$ odniesieniu do zbrodni ZSRR można było zakazać i penalizować zaprzeczanie samym faktom (np. Hołodomor), ale nie ich interpretacje czy wypowiedzi na temat „charakteru” reżimu ${ }^{13}$.

Co więcej, argumentował Jaworski, sądy te uznały, iż ograniczenia prawa do wolności słowa mogą być wprowadzane tylko wtedy, gdy bezpośrednio zagrożone są: integralność terytorialna, suwerenność państwa, porządek publiczny lub prawa innych ludzi, a także gdy zagrożenia te nie mogą być usunięte w inny sposób. Oznaczało to, iż ustawa wprowadzająca zakazy musi wiązać użycie symboli oraz publikację czy emisję materiałów z konkretnymi celami potencjalnych sprawców, stanowiącymi zamach na te wartości. W przeciwnym razie sądowe dowiedzenie winy propagowania reżimów totalitarnych nie będzie możliwe. Ponadto ustawa naruszała także inne prawa człowieka poza wolnością słowa. Po pierwsze, sankcje więzienia za używanie symboli były nieproporcjo-

\footnotetext{
12 Na przykład czerwoną gwiazdę ETPC uznał za symbol między innymi idei międzynarodowej solidarności pracujących.

13 Kwestii tej dotknęła także kryminolożka z Uniwersytetu Lwowskiego Switlana Chyliuk. Na podstawie praktyki orzecznictwa ETPC wykazała, iż Holokaust w międzynarodowym porządku sądowym jest uznany za jedyną zbrodnię, w stosunku do której przepis o karalności zaprzeczania nie ogranicza wolności słowa. Już nawet w stosunku do wymordowania Ormian w Imperium Ottomańskim w latach 1915-1916 nie osiągnięto zgodności, czy było ludobójstwem, zatem w tym przypadku ETPC orzekł przeciwnie (Chyliuk 2015).
} 
nalne do winy ${ }^{14}$. Po drugie, ustawodawca ograniczył inne prawa obywateli: do zrzeszania się, upoważnił bowiem organ administracyjny rejestrujący partie i stowarzyszenia do odmowy rejestracji wyłącznie na podstawie posługiwania się symbolami (a nie prowadzenia działań w celach zakazanych przez prawo); prawo do zgromadzeń, gdyż zdelegalizował spotkania za sam fakt pojawieniach się na nich tych symboli; w końcu prawa wyborcze obywateli, ponieważ odmówil prawa kandydowania osobom wysuniętym przez niezarejestrowane ugrupowania.

Jednocześnie Charkowska Grupa odniosła się pozytywnie do samej idei dekomunizacji i nie zgłosiła zastrzeżeń do zmiany nazw, demontażu pomników i otwarcia archiwów. W jej imieniu Jaworski opowiedział się za osądzeniem zbrodni komunizmu i w ten sposób stworzeniem fundamentu prawnego dla całego tego procesu, lecz nie w procedurze parlamentarnej, a przez odnoszący się do faktów organ sądowy. W dołączonej rekomendacji Grupa proponowała prezydentowi, by „zwrócił” ustawę do parlamentu w celu wprowadzenia do projektu wymienionych zmian. Odnośnie do penalizacji proponowała w ogóle zrezygnować z więzienia i stosować jedynie lżejsze kary, a najlepiej wyłącznie środki odpowiedzialności administracyjnej (Jaworski 2015).

Krytykę tę następnie rozwinęło dwoje młodych naukowców: prawniczka Kateryna Dronowa i historyk Jegor Stadnyj ${ }^{15}$. Przygotowali oni poprawione teksty ustaw, usuwając $z$ nich sformułowania ocenne. We właściwej ustawie dekomunizacyjnej związali wykorzystanie symboliki z konkretnymi działaniami celowymi w taki sposób, aby miały charakter przestępstw umyślnych. Wprowadzili do niej listę zbrodni sowieckich (m.in. Hołodomor, Katyń, pakt Ribbentrop-Mołotow, deportacje). Ich zdaniem uszczegóławianie katalogu zakazanych symboli nie było potrzebne, gdyż o karaniu za ich użycie decydowałby każdorazowo sąd, który brałby pod uwagę przestępczy cel sprawcy określony jako usprawiedliwienie czy pochwalenie ksenofobii, dyskryminacji czy agresji stosowanej przez te reżimy, a także dążenie do odnowienia ich rządów na Ukrainie. Sankcje za łamanie tych przepisów byłyby zrównane $z$ sankcjami z artykułu 300 Kodeksu Karnego Ukrainy, który za wwiezienie, wytwarzanie i rozpowszechnianie utworów zawierających kult przemocy i nienawiści czy nietolerancję i dyskryminację rasową, narodową i religijną przewiduje karę grzywny do 150 miesięcznych płac minimalnych albo ograniczenie wolności do 3 lat (w szczególnych przypadkach do 5 lat). Autorzy ci proponowali, aby decyzje w kwestii rejestracji partii i stowarzyszeń podejmowały wyłącznie sądy, a nie organy administracyjne. Ich zdaniem, utrata prawa do kandydowania

14 Chyliuk wykazała, że sankcja do 10 lat więzienia za złamanie zakazu używaniu symboli (w niektórych przypadkach) narusza zasadę ekonomii represji prawno-kryminalnej, gdyż w ukraińskim systemie karnym zrównuje to przestępstwo ze zgwałceniem, bezprawnym uwięzieniem czy umyślnym ciężkim uszkodzeniem ciała, które spowodowało śmierć osoby (Chyliuk 2015).

15 Obok Marplesa jedyny uczestnik dyskusji w „Krytyce”, który list podpisał. 
w wyborach, zgodnie z Konstytucją Ukrainy, mogła dotyczyć tylko osób skazanych wyrokiem sądu za przestępstwo umyślne, nie zaś takich, które zostały wysunięte przez organizacje niezarejestrowane.

Z kolei w ustawie o „walczących o niepodległość” Dronowa i Stadnyj proponowali, aby chronione było jedynie ich prawo do czci i godności jako jednostek, naruszane przez konkretne wypowiedzi na ich temat przez obywateli kraju i cudzoziemców, nie zaś „legalność” tej walki w ogólności czy dobre imię poszczególnych organizacji. Prawo to jest zresztą — dodali - chronione przez kodeks cywilny w stosunku do wszystkich obywateli, poprawiony przepis nie tworzyłby zatem kategorii uprzywilejowanej (Dronowa, Stadnyj 2015).

Z krytyką ustawy o otwarciu archiwów, a w obronie praw obywateli, wystąpili też niektórzy historycy. Serhij Łunin wskazał na to, że nie chroni ona prawa osób znajdujących się obecnie poza administracją władz Ukrainy (na terytoriach okupowanych, na Białorusi, w Rosji) do zastrzeżenia informacji o swych bliskich represjonowanych w czasach ZSRR, z których część - jak się okaże po ujawnieniu - będzie zapewne nieprawdziwa i/lub zniesławiająca. Obawiał się także, czy w obwodach nieokupowanych, ale znajdujących się blisko frontu, ujawnienie kagebowskich informacji o życiu ludzi przed rokiem 1991 nie będzie wykorzystywane przeciwko osobom lojalnym wobec państwa przez dawnych popleczników reżimu, skrycie popierających separatystów (Łu$\operatorname{nin} 2015)$.

W końcu Władysław Berkowski, przewodniczący rady dyrektorów państwowych archiwów Ukrainy, argumentował, iż brak precyzyjnych definicji w ustawie o archiwach spowoduje poważne szkody. Nie było na przykład jasne, czy użyty termin „ofiara organów represyjnych” dotyczy tylko osób prześladowanych za przekonania i działalność polityczną, czy także na przykład seryjnych morderców, których prawo do rzetelnego procesu też nie było w ZSRR respektowane. Jednocześnie brak spisu „organów represyjnych” mógł spowodować, że za prowadzące stałe represje zostaną uznane nie tylko instytucje bezpieczeństwa, ale także inne struktury państwowe, na przykład placówki naukowe, które zwalniały z pracy badaczy z powodu ich przekonań. Inny problem mógł zrodzić, jego zdaniem, nakaz ujawnienia wszystkich współpracowników organów bezpieczeństwa - wśród nich znaleźliby się także ci, którzy pomogli ująć przestępców kryminalnych. Berkowski wytknął także kierownictwu UIPN brak znajomości standardów przechowywania akt, wynikających z międzynarodowych regulacji archiwistycznych. Wobec niskiego poziomu profesjonalizmu, szczupłości kadr, braku odpowiednich magazynów i niezapewnienia przez ustawodawcę środków budżetowych nakaz przekazania archiwum UIPN wielu milionów jednostek archiwalnych w kraju (tylko w Kijowie ok. 800 tys.) w ciągu przewidzianych $w$ ustawie dwu lat wydawał mu się całkowicie nierealny. Podczas realizacji tej gigantycznej operacji dostęp badaczy do dokumentów argumentował Berkowski (2015) - będzie zawieszony, co spowoduje skutki przeciwne do zamierzeń twórców ustawy. 
W ujęciu ekspertów ustawy wyglądały na dzieło sporządzone bez konsultacji z prawnikami oraz bez wyciągnięcia wniosków z wcześniejszych błędów państw Europy Środkowej. Zawierały rozwiązania niemożliwe do obrony przed ETPC, którego orzecznictwu Ukraina podlega od 1997 roku.

\section{POLE INTELEKTUALNE UKRAINY — KONKLUZJE}

W świetle przytoczonych krytyk uzasadniony wydaje się wniosek, iż przygotowanie ustaw dekomunizacyjnych było, po pierwsze, wysoce zależne od wojny propagandowej z Rosją, po drugie, niesprzyjające dyskusji naukowej i międzynarodowemu wizerunkowi Ukrainy, po trzecie, nieprofesjonalne z prawnego punktu widzenia. U podłoża strategii uchwalenia ich w trybie nadzwyczajnym, nieuwzględnienia w nich gwarancji praw jednostek oraz udziału podmiotów społecznych w kształtowaniu przestrzeni symbolicznej, w końcu nieprzyjmowania argumentów krytyków ${ }^{16}$, leżało przekonanie rządzących, iż Ukraina znajduje się w sytuacji, która wymaga unifikacji pamięci obywateli. Być może niektórzy zwolennicy ustaw mają rację twierdząc, iż ze względu na agresję Rosji opór społeczny wobec implementacji ustaw nie będzie duży i nie przeszkodzi zwolennikom modernizacji kraju na wzór państw UE w utrzymaniu trwałej przewagi w opinii publicznej. Jednak dla historyka pozostaje niezrozumiałe, dlaczego Ukraina, korzystając z wojny, miałaby ostatecznie „oddać” Rosji całą swoją przeszłość w latach 1917-1991, z wyjątkiem osób stawiających opór władzy sowieckiej i służących umacnianiu jej tożsamości kulturowej. Z kolei dla politologa zajmującego się polityką integracji Ukrainy z instytucjami świata zachodniego niezrozumiałe jest, dlaczego przez okazanie braku gotowości do zajęcia się „ciemnymi plamami” swej historii oraz lekceważenie europejskich standardów prawnych wystawia ona na ryzyko niepowodzenia ten właśnie cel strategiczny.

Przeprowadzona analiza pozwala na wyciągnięcie następujących wniosków na temat pola intelektualnego Ukrainy. Po pierwsze, ma ono silnie rozwinięte związki z międzynarodową humanistyką akademicką, głównie w krajach anglosaskich i w Niemczech. Są to przeważnie związki z instytucjami i osobami, które zawodowo zajmują się Ukrainą. Jakkolwiek w życiu intelektualnym wszystkich państw Europy Środkowej i Wschodniej uczestniczą specjaliści od ich historii i współczesności z zagranicy, to jednak w przypadku Ukrainy odgrywają oni wyjątkowo dużą rolę. Ukrainę wyróżnia również to, że instytucje służące pod-

\footnotetext{
16 Jedynym efektem debaty było przegłosowanie przez RN 23 kwietnia poprawek uściślających wyłączenia z zakazu wykorzystania symboliki we właściwej ustawie dekomunizacyjnej (wyłączono dokumenty wydane przez władze reżimów totalitarnych do 1991 roku oraz eksponaty, książki i dzieła sztuki, które znalazły się w muzeach i bibliotekach Ukrainy do chwili wejścia w życie ustawy). RN podjęła także prace nad nowelizacją ustawy o „walczących o niepodległość” w kierunku objęcia „zaprzeczania legalności walki” oraz „obrazy” jej uczestników przepisami kodeksu cywilnego. Jednak do chwili zamknięcia redakcji tego tekstu poprawki nie uchwalono.
} 
trzymywaniu tych związków (jak „Krytyka”) nie są wspierane przez państwo, lecz finansowane głównie przez ofiarodawców z zagranicy i czytelników. Po drugie, pole intelektualne funkcjonuje w dużej mierze w "niszy” medialnej — list ukrainistów do prezydenta był bardzo ogólnikowo wzmiankowany w mediach masowych, a o następującej po nim debacie $z$ reguły w ogóle nie informowano - co ogranicza wpływ jego uczestników na opinię publiczną. Zapewnienie warunków rozwoju jakościowego mediów niezależnych stanowi dziś jedno z podstawowych wyzwań reformatorskich Ukrainy. Po trzecie, słabe są także związki pola intelektualnego z państwowymi instytucjami akademickimi. Humaniści ukraińscy uczestniczą $\mathrm{w}$ tym polu, reprezentując tylko siebie i z reguły nawet nie próbują skłonić na przykład rad naukowych swych instytutów do zajęcia stanowisk w debacie publicznej. Instytucje te zaś przeważnie trzymają się praktyki podległości pochodzącej jeszcze z czasów sowieckich i nie występują publicznie $z$ eksperckimi analizami projektów formułowanych przez władze państwowe.

Po czwarte w końcu, i najważniejsze, pole intelektualne Ukrainy ma słaby wpływ na pole polityki. $Z$ wyjątkiem nielicznych byłych dysydentów, tuż po uzyskaniu niepodległości w 1991 roku, intelektualiści i eksperci z obszaru humanistyki nie podejmują ról na zapleczu polityki, a politycy nie są wsparciem z ich strony zainteresowani. Sądzę, iż wynika to z niskiej jakości elit politycznych, nadal często uważających państwo bardziej za instrument realizacji osobistych interesów niż za wspólnotę obywateli. W tej sytuacji intelektualiści i eksperci nie postrzegają swego zaangażowania w służbę państwową jako czegoś co przyniesie skutek. Wiktor Pińczuk — nie aspirujący do stanowisk państwowych, ale wspierający proces integracji Ukrainy z UE — oraz później Petro Poroszenko byli w polityce ukraińskiej pierwszymi wpływowymi osobami, które budowały wokół siebie intelektualne zaplecze realizacji strategii politycznych. Jednak, jak pokazuje sprawa ustaw dekomunizacyjnych, po dojściu do władzy także obecna głowa państwa nie korzysta $z$ rad środowisk intelektualnych. W tej sytuacji ich miejsce zajmują ludzie, którym nie można odmówić dobrej woli, jednak preferują oni rozwiązania najprostsze, a jednocześnie nienowoczesne oraz wątpliwe $z$ prawnego i naukowego punktu widzenia.

Czy istnieje jakaś droga dla intelektualistów ukraińskich, aby zmienić ten stan rzeczy? Otóż, myślę, że przede wszystkim powinni oni przejąć inicjatywę w ramach swego macierzystego pola. Nie idzie mi o odcięcie się od zagranicznych kolegów czy ich zmarginalizowanie, lecz o inicjowanie krytyki przez osoby rezydujące na Ukrainie i stale biorące udział w jej życiu publicznym. Gdyby to właśnie one wystąpiły do prezydenta $z$ listem zawierającym apel o niepodpisanie ustaw i kontynuowanie pracy nad nimi, to nie miałby on argumentu, iż przyjęcie ich propozycji oznacza cofanie się pod naciskiem zewnętrznym. Najprawdopodobniej przekonywałyby też prezydenta w inny sposób, uwzględniając wrażliwość współobywateli i unikając bezpośredniego włączenia się w pouczający dyskurs historyczny krajów-zwycięzców w drugiej wojnie światowej (państwa anglosaskie, Rosja). 
Jednocześnie ukrainiści zachodni mogliby wyjść naprzeciw kolegom z kraju i wycofać się z roli „zastępczego sumienia” ukraińskiej humanistyki. Jednak jeśli idzie o ich gotowość do realizacji tego postulatu w nieodległej przyszłości, jestem bardziej sceptyczny niż w kwestii dalszej determinacji intelektualistów ukraińskich, by wpływać na życie polityczne w kraju. W każdym razie sądzę, że wskutek przemian rozpoczętych przez Rewolucję Godności rzeczywiście nastał czas na pełne usamodzielnienie Ukrainy.

\section{BIBLIOGRAFIA}

Andruchowycz Jurij, 2015, Andruchowycz: nepidpysannia paketu pro dekomunizaciju serjozno wdarit' po Poroszenku, 15 maja (http://www.radiosvoboda.org/media/video/27018960.html [30.06. 2015]).

Bourdieu Pierre, Wacquant Loïc J. D., 2001, Zaproszenie do socjologii refleksyjnej, tłum. Anna Sawisz, Oficyna Naukowa, Warszawa.

Chyliuk Switłana, 2015, Ociniuwaty ta/abo karaty: jurydycznyj komentarz do "antykomunistycznoho" zakonoprojektu (http://krytyka.com/ua/articles/otsinyuvaty-taabo-karaty-yurydychnyy-komen tar-do-antykomunistychnoho-zakonoproiektu [30.06.2015]).

Dronowa Kateryna, Stadnyj Jegor, 2015, Dekomunizacyjni zakony: propozycija prawok (http://krytyka. $\mathrm{com} / \mathrm{ua} /$ solutions/opinions/dekomunizatsiyni-zakony-propozytsiya-pravok [30.06.2015]).

Hauchman Mychajło, 2015, Sprawa pro dekomunizaciju (http://krytyka.com/ua/solutions/opinions/ sprava-pro-dekomunizatsiyu [30.06.2015]).

Interaktywna karta mist $i$ sit, jaki majut' perejmenuwaty, 2015, (http://www.memory.gov.ua/news/ interaktivna-karta-mist-i-sil-yaki-mayut-pereimenuvati [30.06.2015]).

Hrycak Jarosław, 2014, 26-j procent, abo jak podołaty istoriju, Fond Poroszenka, Kyjiw.

Hrycak Jarosław, 2015, Jarostaw Hrycak: Ukrajina znachodyt'sia miż pekłom i rajem (http://obozrevatel. com/politics/82906-yaroslav-gritsak-ukraina-znahoditsya-mizh-raem-i-peklom.htm [30.06. 2015]).

Jaworski Wołodymyr [Yavorsky Volodymyr], 2015, Analysis of the Law on Prohibiting Communist Symbols, 3 maja (http://khpg.org/index.php?id=1430564974\# [30.06.2015]).

Kojnasz Hala, 2015, „Dekomunizacyjni” zakony: nebezpecznyj potencjat sijannia rozbratu i garantowanyj sudowyj rozhlad $w$ Strasburzi (http://krytyka.com/ua/solutions/opinions/dekomunizatsiyni-za kony-nebezpechnyy-potentsiyal-siyannya-rozbratu-i-garantovanyy [30.06.2015]).

Komorowski Bronisław, 2015, [Bronisław Komorowski gościem programu „Trzech na Jednego” w Polsat News] (http://www.polskieradio.pl/5/3/Artykul/1436307,Wybory-prezydenckie-ost atnie-polityczne-ciosy-Kampania-na-finiszu [30.06.2015]).

Kułyk Wołodymyr, 2015, Pro niejakisni zakony i neczuttywych krytykiw (http://krytyka.com/ua/ solutions/opinions/pro-neyakisni-zakony-ta-nechutlyvykh-krytykiv [30.06.2015]).

Łunin Serhij, 2015, „Antykomunistyczni zakony” z 9 kwitnia: szczo warto byto by pererobyty (http:// krytyka.com/ua/solutions/opinions/zakony-9-kvitnya-shcho-varto-bulo-pererobyty [30.06. 2015]).

Marples David R., 2007, Heroes and Villains: Creating National History in Contemporary Ukraine, Central European University Press, Budapest-New York.

Marples David R., 2015, Wołodymyr Wjatrowycz i ukrajinśki dekomunizacyjni zakony (http://krytyka. $\mathrm{com} / \mathrm{ua} /$ solutions/opinions/volodymyr-vyatrovych-i-ukrayinski-dekomunizatsiyni-zakony [30.06.2015]).

Motyl Ołeksandr, 2015, Dekomunizacija Ukrajiny (http://krytyka.com/ua/articles/dekomunizatsiyaukrayiny [30.06.2015]). 
Olszański Tadeusz Andrzej, 2015, Ukraina: ambitne ustawy dekomunizacyjne (Analizy Ośrodka Studiów Wschodnich; 15 kwietnia 2015) (http://www.osw.waw.pl/pl/publikacje/analizy/2015 -04-15/ukraina-ambitne-ustawy-dekomunizacyjne [30.06.2015]).

Portnow Andrij, 2015a, Pro dekomunizaciju, identycznist' ta istoryczni zakony deszczo inaksze (http:// krytyka.com/ua/solutions/opinions/pro-dekomunizatsiyu-identychnist-ta-istorychni-zakony -deshcho-inakshe [30.06.2015]).

Portnow Andrij, 2015b, Andriej Portnow ob ,istoriczieskich zakonach” 9 aprielia (http://net.abimperio. net/node/3437 [videoblog], [30.06.2015]).

Riabczuk Mykoła, 2015, Chto i czomu powatyw pamjatnyky Leninu, 12 kwietnia (http://gazeta.ua/ articles/opinions-journal/_hto-i-chomu-povaliv-pamyatniki-leninu/625366 [30.06.2015]).

Shevel Oksana, 'De-Communisation Laws' Need to Be Amended to Conform to European Standards, (http:// voxukraine.org/2015/05/07/de-communization-laws-need-to-be-amended-to-conform-to-eu ropean-standards/ [30.06.2015]).

Snyder Timothy, 2014, Majdan? Zniszczyć! „Gazeta Wyborcza”, 22-23 lutego (http://wyborcza.pl/ magazyn/1,136738,15505912,Majdan_Zniszczyc_html [30.06.2015]).

Snyder Timothy, 2015, Timoti Snajder: Dla RF konflikt w Ukrajini - ce telewizijna wijna, 3 czerwca (http://www.dw.com/uk/тімоті-снайдер-для-рф-конфлікт-в-україні-це-телевізійна-війна/a18493285 [30.06.2015]).

Starykow Hryhorij, 2015, Pro dekomunizacyjni zakony: $z$ korystiu i nie bez optymizmu (http://krytyka. $\mathrm{com} / \mathrm{ua} /$ solutions/opinions/pro-dekomunizatsiyni-zakony-z-korystyu-i-ne-bez-optymizmu [30.06.2015]).

Widkrytyj list, 2015, Widkrytyj list naukowców ta ekspertiw-ukrajinoznawciw szczodo tak zwanoho „Antykomunistycznoho zakonu" (http://krytyka.com/ua/articles/vidkrytyy-lyst-naukovtsiv-ta-eksper tiv-ukrayinoznavtsiv-shchodo-tak-zvanoho [30.06.2015]).

Wjatrowycz Wołodymyr, 2006, Stawtennia OUN do jewrejiw: formuwannia pozyciji na tli katastrofy, Ms, Lwiw.

Wjatrowycz Wołodymyr, 2011, Druha ukrajinśko-polśka wijna 1942-1947, Kyjewo-Mohylanśka Akademija, Kyjiw.

Wjatrowycz Wołodymyr, 2015a, Deputatiw zaktykajut' objednatysia dowkoła pamjati (http://www. memory.gov.ua/news/deputativ-zaklikayut-ob-ednatisya-dovkola-pam-yati [30.06.2015]).

Wjatrowycz Wołodymyr, 2015b, Czetwer. Partament. Dekomunizacija (http://blogs.pravda.com.ua/ authors/viatrovych/552577474cf1c/ [30.06.2015]).

Wjatrowycz Wołodymyr, 2015c, Dekonumizacija $i$ akademiczna dyskusija (http://krytyka.com/ua/ solutions/opinions/dekomunizatsiya-i-akademichna-dyskusiya [30.06.2015]).

Zajcew Ołeksandr, 2015, Istorija w zakoni (http://zaxid.net/news/showNews.do?istoriya_v_zakoni \&objectId $=1352972$ [30.06.2015]).

Zinczenko Ołeksandr, 2015a, Dla czoho Instytutu Nacionalnoji Pamjati potribne historyczne lobi w partamenti (http://www.memory.gov.ua/news/dlya-chogo-institutu-natsionalnoi-pamyati-potribne -istorichne-lobi-v-parlamenti-oleksandr-zinch [30.06.2015]).

Zinczenko Ołeksandr, 2015b, Oteksandr Zinczenko. Zwit pro majbutniu pamjat' pro mynute (http:// www.memory.gov.ua/news/oleksandr-zinchenko-zvit-pro-maibutnyu-pamyat-pro-minule [30.06.2015]).

Ustawa o archiwach, 2015, „O dostępie do archiwów organów represyjnych totalitarnego reżimu komunistycznego z lat 1917-1991", projekt nr 2540 (http://zakon1.rada.gov.ua/laws/show/ 316-19 [30.06.2015]). 
Ustawa o drugiej wojnie światowej, 2015, „O uwiecznieniu zwycięstwa nad nazizmem w drugiej wojnie światowej 1939-1945”, projekt nr 2539 (http://zakon1.rada.gov.ua/laws/show/315-19 [30.06.2015])

Ustawa o „walczących o niepodległość”, 2015, „O statusie prawnym i uczczeniu pamięci walczących o niepodległość Ukrainy w XX w.”, projekt nr 2538-1 (http://zakon1.rada.gov.ua/laws/show/ 314-19 [30.06.2015]).

Właściwa ustawa dekomunizacyjna, 2015, „O potępieniu komunistycznego i narodowosocjalistycznego (nazistowskiego) reżimów totalitarnych i zakazie propagowania ich symboliki”, projekt nr 2558 (http://zakon1.rada.gov.ua/laws/show/317-19 [30.06.2015]).

\section{THE DEBATE ON DE-COMMUNIZATION IN UKRAINE IN 2015: HOW POLITICIANS 'WON’ AGAINST INTELLECTUALS}

\section{Sum mary}

This article analyses the de-communization laws passed in Ukraine in May 2015 and the public debate they evoked. The author presents the circumstances in which the laws were passed and describes the thought processes of their drafters from the Ukrainian Institute of National Remembrance. Three discourses are distinguished in the debate: the expert, the national-liberal, and the deconstructivist. With the exception of representatives of the national-liberal discourse, the debaters were critical of the laws and expected either their rejection by the president or their fundamental amendment. In the end, however, the laws passed into force in their first version. Drawing conclusions from this failure of the participants in the debate, the author analyses the relations between the intellectual field and the political field in Ukraine and also the internal relations of the former-between its participants within the country and abroad. In conclusion, the author ponders the strategy that should be adopted by Ukrainian intellectuals for the purpose of increasing their influence on the decision-making of politicians.

\section{Key words/słowa kluczowe}

de-communization / dekomunizacja; public debate / debata publiczna; mass media / środki masowego przekazu; discourse / dyskurs; intellectual field / pole intelektualne; human rights / prawa człowieka; freedom of speech / wolność słowa 